Studia Theologica Varsaviensia

UKSW

$1 / 2021$

Katarzyna Miriam Kaczorowska ${ }^{1}$

ORCID 0000-0002-8742-2657

\title{
PRÓBY ABRAHAMA
}

Abraham $^{2}$ jest kluczową postacią w zbiorowej pamięci Izraela. Jest uważany za przodka, praojca całego Izraela i wzorem do naśladowania w zakresie czynów i cech charakteru. To poprzez Abrahama stworzona została idea Ziemi Obiecanej, ojczyny dla ludu żydowskiego. Judaizm - odmiennie od tradycji chrześcijańskiej, która uznaje za jedyną i wyłączną próbę ofiarowanie Izaaka na Górze Moria (hebr. Akeda - „związanie”, „ofiarowanie”) - postrzega całe życie Abrahama jako ciąg prób i testów, służących potwierdzeniu jego niezwykłego charakteru i niezłomność jego wiary w Jednego Boga. Poprzez analizę życia Abrahama i jego doświadczeń rabini dowodzili mocy wiary Abrahama i jego zaufania w sposobie w jaki

1 Katarzyna Miriam Kaczorowska, radca prawny i doradca podatkowy, studentka studiów doktoranckich III roku Chrześcijańskiej Akademii Teologicznej w Warszawie. Angielska wersja tego tekstu ukazała się wcześniej jako Abraham's Trials in Ancient and Medieval Jewish Writings, „Verbum Vitae” $39 / 4$ (2021) 1357-1376.

2 W całym tekście, dla uproszczenia, będzie konsekwentnie używane imię Abraham niezależnie od etapu jego życia, o którym będzie mowa, chociaż wiadomo, że Najwyższy zmienił Patriarsze imię z Abrama na Abrahama, kiedy ten miał 99 lat (zob. Rdz 17,5), w roku 2039 od czasów Adama (był to także czas obrzezania Abrahama i męskich członków jego rodziny i służby). Analogicznie jak w przypadku Abrama - Abrahama, w całym tekście używane będzie imię Sara, chociaż do czasu zmiany imienia, dokonanej przez Boga, żona Abrahama nosiła imię Saraj (zob. Rdz 17,15). 
Katarzyna Miriam KaczorowskA ${ }^{1}$

ORCID 0000-0002-8742-2657

\section{TRIALS OF ABRAHAM}

Abraham is a key figure in the collective memory of Israel. He is regarded as the Forefather, the progenitor of the entire Israel and the role model to follow with respect to the deeds and character. It was also through Abraham that the idea of the Promised Land, or a homeland for Jewish people, was created. Judaism - differently than the Christian tradition, which recognizes binding of Isaac on Mountain Moriah (in Hebrew - Akedah - "binding") as a sole and single trial - perceives his entire life as a series of tests and trials purposed for confirmation of his unusual character and unshakable faith in One God. By analysing Abraham's life and his experiences the rabbis proved the power of Abraham's faith and confidence of the way he was experiencing it, which, for the believers may become the perfect example to follow.

Akedah - the ultimate test of Abraham's obedience - is one of the most famous and the most powerful narratives in the Hebrew Bible. At the same time it is also a shattering account of devotion to God against all odds, an example of unlimited and unconditional faith and trust. In Jewish tradition it is, however, just one of many

${ }^{1}$ Katarzyna Miriam Kaczorowska, legal counsel, PhD candidate, student of $3^{\text {rd }}$ year of doctoral studies at the Faculty of Theology of Christian Academy of Theology. The enhanced version of this article was originally published as Abraham's Trials in Ancient and Medieval Jewish Writings, ,Verbum Vitae” 39/4 (2021) 1357-1376. 
jej doświadczał, co dla wierzących może stanowić doskonały przykład do naśladowania.

Akeda - ostateczny test posłuszeństwa Abrahama - jest jedną z najsłynniejszych i najpotężniejszych narracji w Biblii hebrajskiej. Jest to jednocześnie wstrząsający opis oddania Bogu wbrew wszelkim przeciwnościom, przykład nieograniczonej i bezwarunkowej wiary oraz zaufania. W tradycji żydowskiej jest to jednak tylko jedna z wielu prób, które służyły Wszechmogącemu do zbadania charakteru i oddania Patriarchy, ostatnia próba. Rabini nie są jednomyślni co do tego, które zdarzenia stanowią próby, jaka była ich kolejność i powody. Tak więc celem tego artykułu jest przedstawienie żydowskiej interpretacji życia Abrahama jako szeregu wyzwań, przedstawionych przez Wszechmocnego Patriarsze i krótkie opisanie tego, jakie wydarzenia tradycja żydowska określa jako próby oraz czy istnieje jedna lub więcej „list” takich prób.

$\mathrm{Na}$ potrzeby niniejszego opracowania przeanalizowano liczne, tradycyjne źródła żydowskie odnoszące się do procesów Abrahama. Wśród wielu komentarzy do Tory wzięto pod uwagę przede wszystkim Pirkei Avot (AP). Ponadto przeanalizowano istotne w tym względzie Midrasz Bereszit Rabba (MBR) i Midrasz Pirke DeRabbi Eliezer (PRE) a także Avot de Rabbi Nathan (ARN). Wśród źródeł pierwotnych należy również wskazać apokryficzną Księgę Jubileuszy (KJ), która w swej treści podąża drogą życia Abrahama, ale nie komentuje jego charakterologii, niemniej można w niej znaleźć liczne szczegóły historyczne dotyczące życia Abrahama przed jego wędrówką do Kanaanu. Wspomniane zostaną także późniejsze komentarze rabinackie (np. Majmonidesa, Rasziego) na temat prób Patriarchy.

\section{PRZYCZYNY PODEJMOWANIA PRZEZ ŻYDOWSKICH MĘDRCÓW I RABINÓW WZMOŻONEJ ANALIZY ŻYCIORYSU ABRAHAMA}

Ani powodów, dla których Bóg wybrał Abrahama, ani szczegółowego opisu prób, które przeszedł Abraham, nie można znaleźć bezpośrednio na kartach Tory. Można je jednak wydobyć z tradycji żydowskiej, w tym z rabinicznej interpretacji życia Abrahama. Ze 
trials which served the Almighty for examining the character and devotion of the Patriarch, the last one. Rabbis are neither uniform as to which events constitute trials or what was their order and reasons. Thus, the purpose of this article is to present the Jewish interpretation of Abraham's life as a series of challenges, presented by the Almighty to the Patriarch and briefly describe, which events the Jewish tradition identifies as trials and whether there is one or more "lists" of such trials.

For the purpose of this study, numerous Jewish traditional sources referring to the trials of Abraham have been analysed. Among many commentaries to Torah, primarily Pirkei Avot (PA) was taken into consideration. Further, Midrash Bereshit Rabbah (MBR) and Midrash Pirke DeRabbi Eliezer (PRE), essential in this respect, have been reviewed, as well as Avot de Rabbi Nathan (ARN). The apocryphal Book of Jubilees (BJ), which in its contents follows the life path of Abraham, but does not comment his characterology, has also to be indicated among primary sources, as numerous historical details regarding life of Abraham prior to his departure to Canaan can be found there. Reference will also be made to later rabbinical commentaries (e.g. Maimonides, Rashi) on the trials.

\section{REASONS FOR PARTICULAR ANALYSIS OF ABRAHAM'S LIFE BY JEWISH SAGES AND RABBIS}

Neither the reasons for God's choice of Abraham or the detailed description of the trials Abraham passed can be directly found on the pages of Torah, but they can be recovered from the Jewish tradition, including rabbinical interpretation of Abraham's life. Due to the key importance of Abraham in the Jewish tradition (he is regarded as the Patriarch, the Forefather and the Founder of the Nation) his life and his personality must have attracted the rabbis and became targeted by their analyses and commentaries. The Torah itself and its certain features were definitely the factors that caused the particular attention and interest. Namely, what rabbis underline, the Torah distinguishes the importance by way of providing more and/or less interest (and 
względu na kluczowe znaczenie Abrahama w tradycji żydowskiej (uważanego za Patriarchę, Praojca i Założyciela Narodu) jego życie i osobowość musiały przyciągać rabinów i stały się celem ich pogłębionych analiz i komentarzy. Szczególną uwagę i zainteresowanie wzbudziła niewątpliwie sama Tora i jej pewne specyficzne cechy. Mianowicie, co podkreślają rabini, Tora różnicuje istotność danej postaci poprzez to, jak ją przedstawi - poświęca się takiej osobie lub osobom mniej lub więcej zainteresowania (i wersetów). Tak więc m.in. Tora nie była szczególnie zainteresowana bałwochwalcą, czcicielem bożków Terachem, ani sprawami związanymi z życiem innych potomków Szema, a jedynie przyszłym znaczeniem Abrahama dla Am Israel i całej ludzkości. Fakt, że Abraham został wybrany przez Boga, a następnie pomyślnie przeszedł dziesięć prób, w judaizmie jest interpretowane jako dowód Boskiej nieomylności. Dlatego życie Abrahama zostało szczegółowo opisane i owa szczegółowość była pierwszą wskazówką dla rabinów do dalszej, drobiazgowej analizy. Poszukiwali wydarzeń z życia Abrahama, dzięki którym Bóg utwierdził się w swoim wyborze, a poprzez które wiara i oddanie Abrahama stawały się coraz silniejsze i bezwarunkowe - wydarzeń, które „wykuwały” Patriarchę jako przyszłego Ojca Izraela.

Innym wyjaśnieniem powodów podjęcia przez rabinów pogłębionej analizy w stosunku do Abrahama może być użycie rzadkiego słowa i/ lub słów, które w podobnym kontekście nie są używane nigdzie indziej w Biblii hebrajskiej. Rabini wyjaśniają, że sama Tora przyciąga uwagę tych, którzy ją studiują, za pomocą kilku słów uży tych incydentalnie i zachęcających poprzez to do bardziej szczegółowego i wnikliwego studiowania danej kwestii ${ }^{3}$. W przypadku Abrahama rabini zwrócili szczególną uwagę na Rdz 22,1 oraz słowo Tộn-nissa - „na próbę”,

3 W komentarzu zawartym w LIII:9 do MBR, rabbi Pinchas w imieniu rabbiego Helkiasza pyta dlaczego w Rdz 21,7 użyto bardzo rzadkiego słowa - ל. - oznaczającego „rzec, powiedzieć”. Rabini wyjaśniają ten przypadek następująco: sama Tora zwraca studiującym jej tekst uwagę na słowa użyte incydentalnie i poprzez to daje wskazówkę do bardziej wnikliwej analizy i interpretacji. W przypadku Abrahama użyte słowo wskazuje, jak uważają rabini, na zawarte w nim proroctwo - numeryczna wartość tego słowa wynosi bowiem sto. W ten sposób - mówią rabini - Sara przez 
verses) to the given person. Thus, e.g. Torah was not particularly interested in the idol-worshipper Terah or in the issues related to lives of other descendants of Shem, but only in the prospective importance of Abraham for Am Israel and the entire humanity. The fact that Abraham was chosen by God and subsequently successfully passed ten trials in Judaism is interpreted as the proof of Divine infallibility. Therefore, his life was described in detail and that was the first hint for the rabbis to further, meticulously analyse it. They were looking for events in Abraham's life, by which God assured Himself in His choice and Abraham's faith and dedication was getting stronger and unconditional - events that were "forging" Abraham as a prospective Father of Israel.

Another explanation for the reasons of undertaking by the rabbis of the scrutiny with respect to Abraham can be the use of the rare word and/or words, which in similar context is not used anywhere else in the Hebrew Bible. The rabbis explain that the Torah itself attracts the attention of those, who study it by way of some words used incidentally and encouraging, in such a way, for more detailed and perceptive study ${ }^{2}$. In case of Abraham, the rabbis turned their particular attention to Gen 22,1, and the word דị - nissa - "to put to the test", which in this specific form ${ }^{3}$ appears exclusively in this verse. Its uniqueness drew attention and intrigued the rabbis.

Also, gematria, i.e. the specific Hebrew numerology, one of the hermeneutical methods of explaining texts, could be the reason for search of the ten special, particular events in Abraham's life, which could be classified as characterological trials increasing the power of authority of Abraham and the respect to him. Thus, it is likely, the numerological analysis also attracted rabbis and caused

2 In the commentary contained in petiha LIII:9 to MBR, rabbi Pinchas on behalf of rabbi Helkiah questions why in Gen 21,7 the very rare word was used - לילמי meaning ,state, say" and explain that it is the Torah that self-explains, providing (by way of use of such specific and/or rare words) guidelines and hints for more detailed analysis.

3 The verb in Piel, third person, masculine, singular. 
które w tej specyficznej formie pojawia się wyłącznie w tym wersecie. Jego wyjątkowość zwróciła uwagę i zaintrygowała rabinów4

Również gematria, czyli specyficzna numerologia hebrajska, jedna $\mathrm{z}$ hermeneutycznych metod wyjaśniania tekstów, mogła być powodem poszukiwania dziesięciu szczególnych, szczególnych wydarzeń z życia Abrahama, które można byłoby zaliczyć do prób charakterologicznych zwiększających moc autorytetu Abrahama i szacunek dla niego. Zapewne zatem analiza numerologiczna przyciągnęła również rabinów i skłoniła ich do dalszej, kompleksowej analizy życia Abrahama, opisanego w Torze, a także do podjęcia rozważań numerologicznych związanych z poszczególnymi wydarzeniami z życia Patriarchy. Takie prawidłowości liczbowe można zaobserwować w odniesieniu do Abrahama i wydarzeń, które rabini interpretowali jako próby ${ }^{5}$. Można m.in. zauważyć, zdaniem rabinów, że poszczególnym wydarzeniom z życia Abrahama odpowiadają liczby, mające szczególne znaczenie dla teologii żydowskiej, takie jak siedem czy dziesięć. Dziesiątka w stosunku do zakładanej liczby prób Patriarchy jest analogiczna do dziesięciu plag egipskich (Wj. 7-12). Podobieństwo dotyczy nie tylko liczby dziesięć jako takiej, ale także historii ukrytej w tej liczbie (a także w liczbie siedem). W obu przypadkach wiąże się to ze śmiercią. Bardziej szczegółowe rozważania na ten temat zostaną przedstawione w odniesieniu do siódmej i dziesiątej próby.

wypowiedzenie rzadkiego słowa oznajmiła Abramowi, że urodzi mu się syn, kiedy będzie miał sto lat.

${ }^{4}$ Czasownik Piel, trzecia osoba, rodzaj męski, liczba pojedyncza.

5 W wyniku badań zapoczątkowanych przez biblistę W.S. Townera sformułowano teorię ,narzędzia siedem - dziesięć”. Taka szczególna metodologia została zauważona np. przez Scotta B. Noegela, który w swoim artykule "Abraham's Ten Trials and a Biblical Numerical Convention" wskazał na tego typu narzędzie w odniesieniu do historii Abrahama W ślad za poglądem Gary’ego Redensburga, Noegel zauważył, że "w Biblii, tam gdzie występuja listy dziesięciu [zdarzeń, słów, obietnic, osób itp. - przyp. aut.], na szczególną uwagę zasługują te wpisy, które zostały umieszczone na siódmej i dziesiątej pozycji” (str. 74). Z tego względu szczególną uwagę po święcono i dokonywano szczegółowej analizy zdarzeń z życia Abrahama, które zostały uznane za siódmą i dziesiątą próbę (zgodnie z PRE są to Przymierze Połówek Bein HaBetarim oraz Akeda). 
their further complex analysis of the Abraham's live as described in the Torah as well as numerological considerations related to particular events in Patriarch's life. Such numerical devices can be observed with respect to the Abraham and the events the rabbis interpreted as trials ${ }^{4}$. They e.g. note that the particular events in the Abraham's life correspond with numbers having specific meaning for the Jewish theology, such as seven or ten. Number ten with respect to the assumed number of Patriarch's trials is analogous to ten Egyptian plagues (Ex. 7 -12). The similarity does not regard only the number ten as such but also the story hidden in this number (as well as in the number seven). In both cases it is connected with death. Some more detailed considerations on it will be made with respect to seventh and tenth trials. It can therefore be assumed that the numerological analysis motivated the rabbis for search of the events in Abraham's life, which could be qualified as characterological tests asserting Patriarch's authority.

\section{TRIAL OR TRIALS?}

Pursuant to the long-lasting Jewish tradition Abraham was put into a number of trials. Commonly ten trials are mentioned and there is a common understanding for recognition of their multitude (and not just a single ,trial"). It is already directly referred to in the PA $(5,3)$, which dates back to II century $\mathrm{BCE}^{5}$, the text later included

4 That specific methodology has been noticed e.g. by Scott B. Noegel, who in his article "Abraham's Ten Trials and a Biblical Numerical Convention" pointed out to such tools as seven-and-ten device. Following Gary Redensburg's view, Noegel noticed that "in the Bible where rosters of ten occur, special prominence is given to the entries listed in the seventh and tenth position" (p.74). For that reason particular focus and detailed analysis was given to the events of the Abraham's life which were listed as seventh and tenth (pursuant to PRE these are the Covenant Bein HaBetarim and Akedah).

5 The rabbis who compiled PA lived in the centuries around the beginning of the Common Era, however, due to the fact that PA contains sayings attributed to sages from Simon the Just who lived around 200 BCE it is believed that PA 
Można zatem przyjąć, że analiza numerologiczna zmotywowała rabinów do poszukiwania wydarzeń z życia Abrahama, które można by zakwalifikować jako testy charakterologiczne potwierdzające autorytet Patriarchy.

\section{PRÓBA CZY PRÓBY?}

Zgodnie z wielowiekową tradycją żydowską Abraham został poddany wielu próbom, a nie jednej. Powszechnie wymienia się dziesięć prób i istnieje powszechny konsensus dla uznania że było ich wiele (a nie tylko jednej ,próby”). Wspomina się o tym już bezpośrednio w dziele PA $(5,3)$, które datuje się na II wiek p.n.e. ${ }^{6}$, którego tekst został później włączony do Miszny ${ }^{7}$, a także w dziele $\mathrm{ARN}^{8}$ (33,1-2). Pełną listę prób dostarcza PRE i inne źródła rabiniczne. Są one później powtarzane w różnych konfiguracjach przez tak wybitnych komentatorów jak Majmonides (Rambam), Nahmanides czy Raszi. Rabini na różne sposoby policzyli lub sklasyfikowali liczbę prób, które przeszedł Abraham. Już ARN $(33,2)$ zauważa przy tym, że niektóre próby mogą być sklasyfikowane jako pary, tzn. można stwierdzić, że dwie próby w podobny sposób dotyczą nakazu rozpoczęcia wędrówki/ wyjścia ( $\mathrm{Rdz} 12,1 \mathrm{n}, 12,10)$, dwie próby dotyczą obu synów Abrahama (Rdz. 21,10, 22,1n) i są dwie próby związane z jego dwiema żonami (Rdz 12,11n, 21,10). Jest też kilka ,pojedynczych” prób, takich jak wojna z królami (Rdz 14), wyjątkowy proces

6 Rabini redagujący PA żyli w wiekach około początku naszej ery, jednak ze względu na to, że PA zawiera wypowiedzi przypisywane mędrcom od Szymona Sprawiedliwego żyjącego około 200 roku p.n.e. uważa się, że dzieło to powstało w II wieku p.n.e., a później został zredagowane i włączone do Miszny.

7 Miszna jest pierwszym wielkim dziełem literatury rabinicznej, składającym się z nauk przekazywanych przez setki lat i ostatecznie skompilowanym około 200 roku n.e. Jest to fundament żydowskiej tradycji ustnej, rozwijanej przez kilka wieków i skodyfikowanej po upadku Świątyni, która jest kontynuowana w Talmudzie, dziele skonstruowanym jako komentarz do Miszny (patrz: sefaria.org).

${ }^{8}$ Avot d'Rabbi Natan to tom towarzyszący PA, przedstawiający sentencje mądrościowe wraz z wyjaśnieniami i opowieściami. Datowany na VII-IX wiek n.e. 
into Mishnah ${ }^{6}$, as well as in ARN (33,1-2) ${ }^{7}$. The full list of trials is provided by PRE and other rabbinical sources. It is later repeated in various configurations by such distinguished commentators as Maimonides (Rambam), Nahmanides and/or Rashi.

The number of trials, which Abraham passed, has been counted and/or classified by the rabbis in various ways. As ARN $(33,2)$ already notices, some can be paired, i.e. it can be stated that two of the trials regard the order to get underway (Gen. 12,1n, 12,10), two trials regard Abraham's both sons (Gen. 21,10, 22,1n) and there are two trials related to his two wives (Gen. 12,11n, 21,10). There are also several ,single” trials such as war with the kings (Gen. 14), unique trial regarding the Covenant of the Parts (Gen. 15), also a single trial, when Abraham was thrown by Nimrod to the furnace in Ur Khasdim (this event is not mentioned in the Hebrew Bible, but it is repetitiously mentioned in midrashim) and just one trial of circumcision (Gen. 17). ARN explains that there were so many trials, because:

so that when Abraham our forefather comes to take his reward, the angels will say: More than us, more than anyone, Abraham deserves his reward, as it says (Ecclesiastes 9:7), «Go, eat your bread with joy, and drink your wine with a happy heart.» Because Abraham was tested with ten trials, and emerged from each one complete, the Holy Blessed One performed ten miracles for his children in Egypt, and brought ten plagues, and

started originating in the II century BC and was later compiled and included into Mishnah.

${ }^{6}$ The Mishnah is the first major work of rabbinic literature, consisting of teachings transmitted over hundreds of years and finally compiled around $200 \mathrm{CE}$. It is a foundation of the Jewish oral tradition developed over several prior centuries and codified after the fall of the Temple, which continues with the Talmud, a work that is structured as commentary on the Mishnah (see: sefaria.org).

7 Avot d'Rabbi Natan ("Fathers of Rabbi Nathan") is a companion volume to PA, presenting maxims of wisdom alongside explanations and stories. Dated to VII-IX centuries CE. 
dotyczący Przymierza Połówek (Rdz 15), a także pojedynczy test, kiedy to Abraham został wrzucony przez Nimroda do pieca w Ur Khasdim (wydarzenie to nie jest wspomniane w Biblii hebrajskiej, ale jest powtarzane w midraszach) i tylko jeden proces obrzezania (Rdz 17). ARN wyjaśnia, że było tak wiele prób, ponieważ:

więc kiedy Abraham, nasz praojciec, przyjdzie po swoją nagrodę, aniołowie powiedzą: Bardziej niż my, bardziej niż ktokolwiek, Abraham zasługuje na swoją nagrodę, jak powiedziano (Koh 9:7): „Nuże więc, jedz radośnie swój chleb i pij w dobrym nastroju swoje wino, gdyż Bogu już dawno miłą jest ta twoja czynność.” Ponieważ Abraham został wypróbowany poprzez dziesięć prób i wyszedł cało z każdej z nich, Święty Błogosławiony dokonał dziesięciu cudów dla swoich dzieci w Egipcie, sprowadził dziesięć plag i dokonał dziesięciu kolejnych cudów na morzu i sprowadził jeszcze dziesięć plag na Egipcjan. nad morzem.

Niektórzy rabini dostrzegają również związek pomiędzy próbami Abrahama a dziesięcioma stwórczymi wypowiedziami Boga (Rdz 1,1-28), dzięki którym został stworzony świat. Abraham został poddany dziesięciu próbom i pomyślnie przeszedł wszystkie, udowadniając, że jest godny podtrzymania świata, stworzonego przez takie dziesięć wypowiedzi Bożych. Te doświadczenia Abrahama nie powinny być postrzegane jako niezależne od siebie. Wszystkie one stanowią jedną ścieżkę, wyznaczoną przez Odwiecznego, która kształtuje moralny i duchowy rozwój Abrahama. Dzięki przymierzom z Bogiem i pomyślnym przejściu prób Abraham stał się pierwszym człowiekiem, który odrzucił fałszywych bogów na rzecz jedynego prawdziwego Boga. Żydzi wierzą, że przymierza między Bogiem a Abrahamem rozciągają się na wszystkich Żydów. Był to początek związku między Bogiem a narodem żydowskim.

Midrasze oraz komentarze rabiniczne różnią się między sobą co do tego, jakie wydarzenia z życia Abrahama należy uznać za próby 
performed ten more miracles at the sea, and brought ten more plagues upon the Egyptians at the sea.

Some rabbis take also notice of relationship between the trials of Abraham and God's ten creative pronouncements (Gen. 1,1-28), by way of which the world was made. Abraham experienced ten trials and passed all of them successfully, proving that he is worthy of sustaining the world created by such ten pronouncements.

These Abraham's experiences should not be perceived as separate from each other. They all constitute one path, scheduled by the Eternal, which shapes the moral and spiritual development of Abraham. Through the covenants with God and successful passing the tests, Abraham became the first human to reject false gods in favour of the one true God. Jews believe that the covenants between God and Abraham extends to all Jews. It was the start of the relationship between God and the Jewish people.

Midrashim and rabbinical commentaries differ between themselves with respect to which events in the life of Abraham should be regarded as the trials and what was their order. They, however, are almost unanimous (with one single exception contained in the BJ) in viewing Akedah - binding of Isaac and his offering at Mount Moriah as the last, tenth trial. They differ as to when putting Abraham to testing started. For example, in line with the account provided in PRE (below in more detail) Abraham passed his two initial tests yet before receiving God's call to leave Haran. The call to go forth from Haran and set out to Canaan with Sarah and Lot was only the third trial. On the other hand some midrashim as well as such contemporary American researchers Israel Drazin and Stanley Wagner (describing the views of the rabbis in their study to Targum Onkelos) indicate that the first of Abraham's trials took place in Gen. 12,1, when Abraham without any hesitation with respect to God's lech lecha 8 - "go for yourself" agreed to leave his family home and left

\footnotetext{
8 As with many phrases in the Torah, "lech lecha" is enigmatic and open to many interpretations. There is the understanding of lech lecha as "Go to yourself," an internal
} 
i jaki był ich porządek. Są jednak prawie jednomyślni (z jednym wyjątkiem zawartym w KJ) w postrzeganiu Akedy - związania Izaaka i jego ofiarowania na Górze Moria jako ostatniej, dziesiątej próby. Różnią się natomiast co do tego, kiedy rozpoczęto wystawianie Abrahama na próbę. Na przykład, zgodnie z relacją przedstawioną w PRE (bardziej szczegółowo poniżej), Abraham przeszedł swoje dwie początkowe próby jeszcze przed otrzymaniem Bożego wezwania do opuszczenia Haranu. Wezwanie to i wyruszenia do Kanaanu z Sarą i Lotem było dopiero trzecią próbą. Z drugiej strony niektóre midrasze, a także współcześni badacze, jak np Israel Drazin i Stanley Wagner (opisujący poglądy rabinów w swoich badaniach Targumu Onkelosa) wskazują, że pierwsza z prób Abrahama nastąpiła, jak wskazano w Rdz. 12,1, gdy Abraham bez wahania w odniesieniu do Bożego lecha lecha9 - „wyjdź, idź naprzód” zgodził się opuścić rodzinny dom i wyszedł z Haranu w nieznane. Wskazali, odnosząc się do rabinicznych komentatorów, na dwa możliwe sposoby interpretacji ,prób” (i) wersja przyjęta przez Nachmanidesa, Abrahama ibn Ezrę i Judę Haleviego, zakładają a, że Bóg wiedział, jak zareaguje Abraham, ale nadal zamierzał uwolnić jego potencjał i zwiększyć jego samoświadomość (ii) wersja RaDaKa (Davida Kimhi), Hezekiasza ben Manoah (Chizkuni) i Majmonidesa, którzy wskazują, że historia prób Abrahama została opowiedziana, aby nauczyć nas, ale nie samego Abrahama, jak żyć własnym życiem. Rabini, cytując słowa Boga wypowiedziane do Abrahama lecha lecha, byli zdania, że Wiekuisty musiał już ta próbą w jakiś szczególny sposób sprawdzić „sprawiedliwośćc ${ }^{10}$ A Abrahama. W ten sposób starali się zidentyfikować je w Księdze Rodzaju i szczegółowo je przeanalizować. Tora nie zawiera takich informacji, dlatego poszukiwania należy

9 Jak wiele fraz w Torze, ,lech lecha” jest enigmatyczna i otwarta na wiele interpretacji. Lech lecha rozumie się m. in. jako wezwanie „Idź do siebie/ wejdź w siebie", zachętę do wewnętrznej wędrówki. Została ona również przetłumaczona jako: „Wyjdź, idź po siebie, idź naprzód, wyjdź”. To znaczy, oddziel się od miejsca, w którym jesteś - wezwanie odbijające się szerokim echem.

10 Drazin - Wagner, Onkelos, 132-137 
Haran. They indicated, referring to later commentators, two possible ways of interpreting the "trials" (i) option according to Nahmanides, Abraham ibn Ezra and Judah Halevi, assuming that God knew, how Abraham would react but still intended to unleash his potential and increase it for the sake of self-consciousness (ii) option according to RaDaKh (David Kimhi), Chazkunee and Maimonides, who indicate that the story of Abraham's trials was told in order to teach us, but not Abraham, how to live our lives. The Rabbis, quoting God's words said to Abraham lech lecha were of the view that the Eternal must have already in some particular way checked before the trials of Abraham's "righteousness". Thus they strived to identify them in the Book of Genesis and analyse them in detail. Torah does not contain any such information, thus the search should be carried out in commentaries and rabbinic studies. Below the detailed orders of trials according to several, below-referred sources will be presented.

\subsection{Pirke Avot}

Pirke Avot (PA), originated around the II century BCE, later included into Mishnah, is the oldest rabbinic work, where the ten trials are explicitly mentioned. PA indicates that "for ten trials Avraham, our Father, was put, and all he passed through, this shows the love of Avraham, our Forefather, [to God]", but it does not specify which were these tests. PA stresses the importance of the number ten, indicating e.g. "ten utterances" of world's creation, ten generations from Adam to Noah and then another ten from Noah do Abraham, ten trials of Abraham and then ten miracles and then ten plagues in Egypt. By that the rabbis wanted to emphasize the uniqueness and importance of Abraham. One of the later commentators of PA,

odyssey. It has also been translated as: "Get you out, Go for yourself, Go forth, Go out." That is to say, disassociate from where you are; a call with an external echo to it.

${ }^{9}$ Drazin - Wagner, Onkelos, 132-137. 
prowadzić w komentarzach i opracowaniach rabinicznych. Poniżej przedstawione zostaną szczegółowe porządki prób według kilku, poniżej przytoczonych źródeł.

\subsection{Pirke Avot}

Dzieło Pirke Avot (PA), powstało około II wieku p.n.e., później zostało włączone do Miszny (traktat Nezkin). Jest ono najstarszym dziełem rabinicznym, w którym wyraźnie wspomniano o dziesięciu próbach. PA wskazuje, że „na dziesięć prób wystawiony został nasz praojciec Abraham i wszystkie je zniósł, zaświadczając tym, jak wielka jest jego miłość do Boga.", ale nie precyzuje, jakie były te próby. PA podkreśla znaczenie liczby dziesięć, nawiązując np. do „dziesięciu wypowiedzi” o stworzeniu świata, dziesięciu pokoleń od Adama do Noego, a potem kolejnych dziesięciu od Noego do Abrahama. Wskazuje dziesięć prób Abrahama, a potem dziesięć cudów, a potem dziesięć plag w Egipcie. Poprze takie nawiązania chciano podkreślić wyjątkowość i znaczenie Abrahama. Jeden z późniejszych komentatorów AP, Jonasz Gerondi ${ }^{11}$ wymienia te próby szczegółowo, wskazując jako pierwszą ognisty piec Nimroda, jako drugą lech lecha, a następnie wędrówkę do Egiptu, zabranie Sary przez Faraona, wojnę królów jako piątą, potem obrzezanie, zabranie Sary do Abimelecha, odesłanie Hagar i Izmaela, Akede (dziewiąta w tej liście) oraz pogrzeb Sary jako dziesiątą i ostatnią. Nie są one jednak jeszcze wymienione w samym PA. Dopiero późniejsze prace rabiniczne zawierają bardziej szczegółowe wykazy.

11 Jonasz Gerondi (Rabbejnu Jonasz, zm. 1264) był hiszpańskim rabinem z Gerony, talmudystą i etykiem. Jego najbardziej znane dzieło Sha'arei Teshuva, jest kompleksową pracą o pokucie. Napisał także chiddushim (nowele talmudyczne) do szeregu traktatów, cytowanych później przez współczesnych mu i późniejszych autorów. Był jednym z najbardziej znaczących oponentów wobec dzieł filozoficznych Rambama (Majmonidesa). 
Rabbeinu Yonah Gerondi ${ }^{10}$ lists specifically these tests, indicating the fiery furnace of Nimrod as the first one, lech lecha as the second, then departure to Egypt, taking Sarah to Pharaoh, war of kings as the fifth, then the circumcision, taking Sarah to Abimelech, sending away Hagar and Ishmael, Akedah (which is ninth in this list) and the burial of Sarah as the tenth and last one. They are, however, not listed in the PA itself, yet. Only the later rabbinic works provide for more detailed lists.

\subsection{Book of Jubilees}

The $\mathrm{BJ}$ is a pseudepigraphic work dating back to the times of the Second Temple, in II century $\mathrm{BCE}^{11}$. Pursuant to the tradition it is a secret revelation of the angel of „Divine Presence” to Moses during his second Ascend to Mount Sinai (it is therefore also called the Testament of Moses and/or Moses' Apocalypse). The chapters 11-22 refer to the story of Abraham. There are only two verses in the entire description that refer to the trials of Abraham, including one verse listing specifically six of these trials by way of which God tested the Patriarch's character and faith. In the verse 17 of the 17 chapter the following description can be found ${ }^{12}$ :

The Lord knew that Abraham was faithful throughout all his afflictions, for He had tried him through his country and with famine, and had tried him with a wealth of kings, and had tried him again with his wife, when she was torn from him, and with circumcision, and tries him through

${ }^{10}$ Yonah Gerondi (Rabbeinu Yonah, d. 1264) was a Spanish rabbi, Talmudist and ethicist. His best-known work is Sha'arei Teshuva, a comprehensive work on repentance. He also wrote chiddushim (Talmudic novellae) on a number of tractates, quoted by contemporaries and later authors. He was one of the most prominent opponents of the Rambam's philosophical works.

${ }^{11}$ Skolick, Encyclopaedia, XI.473.

${ }_{12}$ Lumpkin, Encyclopaedia, 198. 


\subsection{Księga Jubileuszy}

KJ to dzieło pseudoepigraficzne, datowane na czasy Drugiej Świątyni, powstałe ok. II wieku p.n.e. ${ }^{12}$ Zgodnie z tradycją jest to tajemne objawienie anioła „Boskiej Obecności” Mojżeszowi podczas jego drugiego wejścia na Górę Synaj (stąd też nazywane jest też Testamentem Mojżesza lub Apokalipsą Mojżesza). Rozdziały 11-22 odnoszą się do historii Abrahama. W całym opisie są tylko dwa wersety, które odnoszą się do prób Abrahama, w tym jeden werset wymienia dokładnie sześć z tych prób, za pomocą których, wg autorów KJ, Bóg testował charakter i wiarę Patriarchy. W wersecie 17 z 17 rozdziału znajduje się następujący opis ${ }^{13}$ :

Pan wiedział, że Abraham był wierny we wszystkich utrapieniach, których doświadczał, ponieważ doświadczył go poprzez swój kraj i poprzez głód, doświadczył go poprzez bogactwo królów i ponownie wypróbował go poprzez jego żonę, gdy została mu odebrana, i przez obrzezanie, i poddaje go próbie poprzez Ismaela i Hagar, jego służącą, kiedy [Abraham] ich odesłał.

W dalszej części wersetu 18 znajduje się opis uzupełniający: „We wszystkim, w czym go doświadczył, okazał się wierny, a dusza jego nie zniecierpliwiła się i nie zwlekała z działaniem, nie zwlekał, bo był wierny i miłował Pana".

Analizując przytoczoną wyżej część KJ, można wskazać sześć z dziesięciu prób wymienionych następnie w historii Abrahama zawartej w PRE. KJ wspomina ziemię obiecaną - Kanaan - prawdopodobnie odnosi się do nakazu opuszczenia Haranu i wyruszenia do Kanaanu (KJ 12:22), głodu i wyjazdu do Egiptu (KJ 13:10), bogactwa Abrahama uzyskanego od królów (KJ 13:28-29). Kolejne próby to sytuacja, gdy żona Abrahama (Sara) została mu siłą odebrana przez

\footnotetext{
12 Skolick, Encyclopaedia, XI.473.

13 Lumpkin, Encyclopaedia, 198.
} 
Ishmael and Hagar, his maid-servant, when he sent them away.

Further in the verse 18 there is a supplementary description: „In everything, that He had tried him, he was found faithful, and his soul was not impatient, and not slow to act he was not slow to act, because he was faithful and lover of the Lord".

Having analyzed the above-referred part of the $\mathrm{BJ}$ it is possible to identify six of the ten trials mentioned in the Abraham's story in PRE. BJ mentions the promised land - Canaan - it probably refers to the commandment of departing from Haran and setting off to Canaan (BJ 12:22), famine and departing to Egypt (BJ 13:10), Abraham's wealth obtained from the kings (BJ 13:28-29). The subsequent trials are the case when the wife of Abraham (Sarah) has been taken by force from him by Pharaoh (BJ 13:1315), circumcision of Abraham and all of his family and servants (BJ 15:23-24) and casting out of Ishmael and Hagar (BJ 17:4-8). As it can be clearly seen, the BJ also does not list all the trials, but it confirms the majority of them. It also confirms the accepted total number of trials as further in the Chapter 19:8 it explicitly mentions the tenth test: untypically BJ regards as such not the Akedah of Isaac (this story is discussed in the preceding Chapter 18) but the death of Sarah and Abraham's efforts to purchase the Machpelah Cave. BJ explicitly states that that was the last test of Abraham ${ }^{13}$ : "This a tenth trail wherewith Abraham was tested, and he was found faithful and patient in spirit". Thus, already an early Jewish tradition, preserved in the BJ confirms the common belief, present in Second Temple times regarding ten trials. Their specification, however, differs in details from the interpretation preserved in later texts.

13 Lumpkin, Encyclopaedia, 199. 
Faraona (KJ 13:13-15), obrzezanie Abrahama i całej jego rodziny oraz sług (KJ 15:23-24) i wyrzucenie Izmaela i Hagar (KJ 17:4-8). Jak widać, KJ również nie wymienia wszystkich prób, ale potwierdza identyfikację większości z nich. Potwierdza również przyjętą całkowitą liczbę prób, ponieważ dalej w rozdziale 19:8 wyraźnie wspomina o dziesiątym teście: nietypowo KJ uważa za taką nie Akedę Izaaka (ta historia jest omówiona w poprzednim rozdziale 18), ale śmierć Sary i starania Abrahama o zakup Jaskini Machpela z przeznaczeniem na miejsce pochówku zmarłej żony. KJ wyraźnie stwierdza, że to była ostatnia próba Abrahama ${ }^{14}$ : „Jest to dziesiąta ścieżka, na której Abraham został wypróbowany i okazał się wierny i cierpliwy w duchu". Tak więc już wczesna tradycja żydowska, zachowana w KJ, potwierdza powszechne przekonanie, obecne w czasach Drugiej Świątyni, dotyczące tego, że Abraham poddany został dziesięciu próbom. Ich specyfikacja różni się jednak szczegółami od interpretacji zachowanej w późniejszych tekstach.

\subsection{Midrasz Pirke DeRabbi Eliezer}

Pirke d'Rabbi Eliezer ${ }^{15}$ to midrasz, który na nowo opowiada i rozwija opowieści zawarte w Torze, od stworzenia świata po historię trądu Miriam. PRE zawiera najpełniejszy opis prób Abrahama, łącznie z ostatnią (zgodnie z tym tekstem źródłowym), która, wg PRE, miał miejsce na Górze Moria. PRE nie jest oczywiście jedynym tekstem żydowskim, w którym mowa jest o próbach Abrahama. Niemniej jednak PRE jest szczególnie obszerny i ze względu na swoją bogatą treść i złożoność jest szczególnie cennym źródłem do analizy. Jego zasadnicza redakcja datowana jest na VIII wiek n.e. ${ }^{16}$

14 Lumpkin, Encyclopaedia, 199.

15 Friedlander, Pirke.

16 Redakcję tekstu szacuje się na okres VIII-IX wieku, ale zawiera on tradycję znacznie wcześniejszą (Stemberger, Wstęp, 131-159). Stemberger stwierdza, że „dzieło wydaje się pochodzić z VIII lub IX wieku” [ponieważ cytuje je już na początku IX wieku Pirqoi ben Baboi] (Stemberger, Wstęp, 329). 


\subsection{Midrash Pirke DeRabbi Eliezer}

Pirke d'Rabbi Eliezer ${ }^{14}$ is a midrash that retells and expands upon the stories of the Torah, from the creation of the world through the story of Miriam's leprosy. PRE contains the fullest description of the trials of Abraham, including the last one (in accordance with this source text) that took place on Mount Moriah. PRE is obviously not the only Jewish text, where the trials of Abraham are referred to. Still PRE is very extensive and due to its broad contents and complexity it is a particularly valuable source for analysis. Its principal redaction dates back to VIII century $\mathrm{CE}^{15}$ and it was made almost right after the final redaction of Talmudim had been completed, which suggests that it can use some additional portion of knowledge, that is not yet contained e.g. in the MBR ${ }^{16}$. PRE makes referrals to Babylonian Talmud, however it originated probably in Palestine, as the majority of rabbis quoted come therefrom, and it uses the descriptions of the Abraham's story from other rabbinical sources. Below the detailed list of the ten trials based on the account provided in the PRE has been presented.

The first trial ${ }^{17}$ was the trial of salvation - survival of Abraham and it was directly connected with his birth. At that day a new star appeared on the skies. The king Nimrod's magicians noticed that and concluded that the person who had just been born, shall become a significant threat to Nimrod. That is why they intended to kill him. From the contents of BJ (complementary to PRE in this context) it is known that Nimrod had all male new-borns killed in the year, when

14 Friedlander, Pirke.

15 The redaction of the text is estimated for the period of VIII-IX centuries, but it contains a much earlier tradition (Stemberger, Introduction, 131-159). Stemberger states that ,the work appears to have originated in the eighth or ninth century" [it seems that it is already quoted in the early ninth century by Pirqoi ben Baboi] (Stemberger, Introduction, 329).

16 Stemberger concludes that, it uses a wealth of older tradition and shows itself aware of the pseudepigrapha; it may also have adopted entire chapters from other sources, almost without alteration".

17 Friedlander, Pirke, 187-188. 
i miała miejsce niemal zaraz po zakończeniu ostatecznej redakcji Talmudów, co sugeruje, że może on wykorzystywać jakąś dodatkową porcję wiedzy, która nie jest zawarta m.in. w MBR ${ }^{17}$. PRE odwołuje się do Talmudu Babilońskiego, jednak wywodzi się on prawdopodobnie z Palestyny, z którego pochodzi większość cytowanych rabinów i wykorzystuje opisy historii Abrahama z innych źródeł rabinicznych. Poniżej przedstawiono szczegółową listę dziesięciu prób na podstawie relacji podanej w PRE.

Pierwsza próba ${ }^{18}$ była próbą ocalenia - przetrwania Abrahama i była bezpośrednio związana $\mathrm{z}$ jego narodzinami. W tym dniu na firmamencie ukazała się nowa gwiazda. Zauważyli to magowie króla Nimroda i stwierdzili, że ten, kto się teraz narodził, będzie wielkim zagrożeniem dla Nimroda. Dlatego chcieli go zabić. Z treści KJ wiadomo, że Nimrod zabił wszystkich męskich noworodków w roku, w którym urodził się Abraham. Terach ukrył Abrahama w pieczarze i ukrywał go tam przez 13 lat. Kiedy Abraham wyszedł z jaskini, rozmawiał językiem Boga - językiem pierwszych osadników po Potopie, zanim Wiekuisty pomieszał później języki ${ }^{19}$. W czasie, gdy przebywał w ukryciu, Abraham poznał Wiekuistego i znienawidził jakiekolwiek idole i bożki Nimroda. PRE cytuje Ps. 84,12: „Bo Pan Bóg jest słońcem i tarczą, Pan hojnie darzy łaską i chwałą, nie odmawia dobrodziejstw postępującym nienagannie".

Druga próba ${ }^{20}$ nastąpiła po wyjściu z jaskini, gdy Abraham służył swemu ojcu w domu rodzinnym. Po tym jak Abraham dopuścił się zniszczenia bożków, Terach oddał go Nimrodowi pod sąd. Abraham został skazany na więzienie, w którym spędził 10 lat: 3 lata w Kuthi i 7 lat w Budri. Numerologia rabiniczna wskazuje na ważne cyfry i liczby, w tym 7 i 10. Siódma plaga (Wj 9,25) i dziesiąta plaga

17 Stemberger konkluduje, że MBR ,,korzysta z bogactwa starszej tradycji i wykazuje świadomość istnienia pism pseudoepigraficznych; być może również przejął całe rozdziały z innych źródeł, prawie bez zmian”.

18 Friedlander, Pirke, 187-188.

19 MBR XLII:8, TB Sotah 12a.

20 Friedlander, Pirke, 188. 
Abraham was born. Terah hid Abraham in the cave and kept him in hiding for 13 years. When Abraham left the cave he was speaking the language of God - the language of first settlers after the Flood, before the Eternal mixed the languages ${ }^{18}$. During the time of hiding Abraham got to know the Eternal and despised all the Nimrod's idols and gods. PRE quotes Ps. 84,11: "For God is a sun and shield: the LORD will give grace and glory: no good thing will he withhold from them that walk uprightly".

The second trial ${ }^{19}$ occurred after leaving the cave, when Abraham was serving his father at home. Abraham destroyed the idols and Terah handed him over to Nimrod and brought to court. He was sentenced to prison, where he spent 10 years: 3 years in Kuthi and 7 years in Budri. Rabbinic numerology indicates here important numbers, including 7 and 10. Seventh Egyptian plague (Ex. 9,25) and tenth plague (Ex. 12,29-30) were associated with death. Abraham spent 10 years imprisoned and was also near to death: right there in the end of his captivity by order of Nimrod ${ }^{20}$ he was thrown into the furnace. But the King of Glory raised His right hand and extracted Abraham from the furnace and said to him, paraphrasing the verse from Gen.

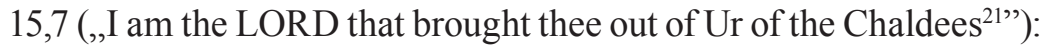
„I am the Lord that brought thee out of the furnace" [Nimrod's]. It is worth noting that the Hebrew expression רוּא (Ur) also in Babylon used to be associated with fire and furnace - therefore the rabbis note Abraham lived in Babylon: Ur Khasdim (Ur of the Chaldees) the place where Terah with his family settled.

The third trial according to rabbis ${ }^{22}$ is Abraham's migration from Haran to Canaan (the lech lecha trial). Pursuant to PRE, Abraham's father Terah and his mother Athrai died long after Abraham left

18 MBR XLII:8, TB Sotah 12a.

19 Friedlander, Pirke, 188.

20 TB, Baba Bathra, 91a.

${ }^{21}$ Biblical quotations pursuant to King James Bible, edition available on-line: https://kingjames.bible if not indicated otherwise.

22 Friedlander, Pirke, 188. 
(Wj 12,29-30) kojarzyły się ze śmiercią. Abraham spędził w uwięzieniu łącznie 10 lat i także był bliski śmierci: tam bowiem właśnie, pod koniec swej niewoli, został na rozkaz Nimroda ${ }^{21}$ wrzucony do pieca. Ale Król Chwały wyciągnął swoją prawą dłoń (MBR, XLIV:4) i wyrwał Abrahama z pieca i rzekł do niego, parafrazując werset z Rdz 15,7 („Ja jestem Pan, który ciebie wywiodłem z Ur Chaldejskiego ${ }^{22}$...”): „Ja jestem Pan, który ciebie wywiodłem z pieca [Nimroda]...”. Co istotne, hebrajskie רוּא (Ur) także w Babilonii kojarzyło się z ogniem i piecem - stąd rabiniczna uwaga o zamieszkaniu Abrahama w Babilonii: Ur Kasdim (Ur Chaldejskie) - miejscu, w którym żył Terach z rodziną.

Trzecią próbą ${ }^{23}$ według rabinów była emigracja Abrahama z Haranu do Kanaanu (próba lech lecha). Według PRE ojciec Abrahama Terach oraz jego matka Athrai zmarli w Haranie - Terach w roku 2082 od czasów Adama, zaś daty śmierci matki PRE nie podaje (TB Baba Bathra, 91a). PRE wskazuje, że migracja jest najtrudniejszą decyzją dla człowieka, bardziej niż dla jakiegokolwiek innego stworzenia $^{24}$ (TB Ketubot 28b), bazując na Iz 22,17: „Oto Pan zrzuci cię, człowiecze, z wielkim rozmachem i uchwyci cię jednym chwytem”.

Czwarta próba to, jak podaje PRE, głód na ziemi Abrahama w Kanaanie ${ }^{25}$. PRE wspomina, że jest to pierwsza klęska głodu od czasu zakończenia potopu - co się kłóci z informacją pochodzącą od rabinów w MBR XXV:3, gdzie wspomniano o dwóch klęskach głodu przed czasami Abrahama. Raszi w komentarzu do Rdz 12,10 wskazał, że klęska suszy i głodu wystąpiła tylko w Kanaanie po to, by skłonić Abrahama do podróży do Egiptu, jako najbliższej położonego, sąsiedniego kraju.

21 TB, Baba Bathra, 91a.

22 O ile nie wskazano inaczej, cytaty biblijne pochodzą z Biblii Tysiąclecia, czyli Pismo Święte Starego i Nowego Testamentu, wyd. 5, Poznań 2007 (BTP), wydanie dostępne on-line: http://biblia-online.pl/Biblia/Tysiaclecia/Ksiega-Rodzaju/1/1

23 Friedlander, Pirke, 188.

24 TB Ketubot 28b.

25 Friedlander, Pirke, 189. 
Haran, Terah in the year 2082 from Adam's times and the date of death of Abraham's mother is not provided. PRE points out that migration is the most difficult decision for every human being, far more than for any other creature ${ }^{23}$, based on Is. 22,17: „, Behold, the LORD will carry thee away with a mighty captivity, and will surely cover thee".

The fourth trial was, as it is provided in PRE the famine in the land of Abraham in Canaan ${ }^{24}$. PRE notes that it is the first famine since the Flood - which is contrary to the account provided by the rabbis in the MBR where to famines are mentioned prior to the times of Abraham. Rashi in his commentary indicates that that famine and draught occurred in Canaan only in order to force Abraham to the journey to Egypt, which was the closest neighbouring country.

The fifth trial took place when Sarah, Abraham's wife was taken away from Abraham and brought to pharaoh for to become his wife ${ }^{25}$. Abraham did not object, because he believed that God would save Sarah and himself. Rabbi Joshua ben Korchah (in some other versions of PRE: rabbi Tarphon) indicates that Sarah was taken to Pharaoh on the day of Pesach (it was Passover night, and the Holy One, blessed be He, brought upon Pharaoh and upon his house great plagues, to make known that thus in the future would He smite the people of his land, as it is said). Once Sarah was brought to the court, the marriage ceremony was carried out and the marriage document was written down. Pharaoh promised in this document that in case of divorce (upon issuing get) Sarah would be provided with wealth including gold, silver, servants and land in Goshen. Immediately after the ceremony God punished pharaoh and his servants with disease and plagues (Gen. 12,17). Both Pharaoh and his servants were afflicted with the impotence and the monarch could not consume his marriage with Sarah. This sign from God received by Pharaoh was prophetic, as by way of that pharaoh learned from the Highest that he could not consume this marriage nor have any children.

\footnotetext{
23 TB Ketubot 28b.

24 Friedlander, Pirke, 189.

25 Friedlander, Pirke, 189-190.
} 
Piąta próba miała miejsce, gdy Sara, żona Abrahama została zabrana do Faraona, aby zostać jego żoną ${ }^{26}$. Abraham nie protestował, bo wierzył, że Bóg uratuje Sarę i jego samego z tej sytuacji. Rabbi Joshua b. Korchach (w innych wersjach PRE: rabbi Tarfon) twierdzi, że Sara została wzięta do Faraona w dzień Paschy. Po przyprowadzeniu Sary na dwór Faraona, odbyła się ceremonia ślubu i spisanie listu małżeńskiego. Faraon w traktacie małżeńskim obiecał, że w przypadku listu rozwodowego (get) przekaże sowitą odprawę dla Sary w postaci złota, srebra, służby i ziemi Goszen. Po ceremonii ślubnej Bóg natychmiast ukarał Faraona i jego służbę chorobą i plagami (Rdz 12,17). Zarówno Faraon, jak i jego służba porażeni zostali impotencją i władca nie był w stanie skonsumować małżeństwa z Sarą. Boży znak, jaki otrzymał Faraon, był proroczy, ponieważ w ten sposób Faraon dowiedział się od Najwyższego, że nie może skonsumować tego związku i mieć dzieci z Sarą. Bóg przekazał informację Faraonowi, że potomkowie Abrahama tutaj wrócą (do ziemi Goszen), a Wiekuisty tym razem mocniej i śmiertelnie porazi jeszcze raz Egipt. Skąd to wiadomo? W Wj 11,1 jest napisane: ,Jeszcze jedną plagę ześlę na faraona i na Egipt". W związku z powyższym Faraon uwolnił Sarę, dając jej list rozwodowy i w odprawie przekazał duży majątek, w tym także ziemię w Goszen, gdzie później Izraelici znajdą się w niewoli egipskiej. To z tej relacji dowiadujemy się o podarunku Faraona, który ofiarował Sarze swoją córkę Hagar $^{27}$, którą według relacji w PRE miał z jedną z konkubin ${ }^{28}$. Abraham z Sarą opuszczają Egipt z rodziną i udają się do ziemi Filistynów, aby tam odpocząć ${ }^{29}$. Podobna historia, trochę później, powtarza się z królem Abimelechem ${ }^{30}$, który podobnie jak faraon dotknięty został niemocą - dzięki kolejnej interwencji Boga Sara i Abraham stają się bogaci.

26 Friedlander, Pirke, 189-190.

27 Freedman - Simon, The Midrash, XLV:1.

28 Vanderkam, Jubilees, 464.

29 Friedlander, Pirkei, 191.

30 Tb Baba Kama 92a. 
God provided Pharaoh with the information that the descendants of Abraham would return (to the Land of Goshen) and the Almighty would strike Egypt stronger and lethally once again. Where does this information come from? In Ex. 11,1 it is written that ,Yet will I bring one plague more upon Pharaoh, and upon Egypt". Thus, the Pharaoh freed Sarah providing her with divorce letter and as a „severance pay" he gave her a significant property, including the Land in Goshen, where the Israelites later were enslaved. This is the account from which we learn about the pharaoh's gift, who gave Sarah his own daughter Hagar ${ }^{26}$, born from a concubine, as her handmaid ${ }^{27}$. Abraham and Sarah left Egypt with their entire family and go to the land of Philistines to rest ${ }^{28}$. Similar story happens again later with king Abimelech ${ }^{29}$, who similarly to pharaoh experienced the impotence - thanks to another God's intervention Abraham and Sarah become wealthy.

The sixth trial ${ }^{30}$, was the victory of Abraham over the four kings (Gen. 14,1-16), "(when) all the kings came against him to slay him". Thanks to intervention and help of God, Abraham and his $318^{31}$ armed and trained servants fought off the attack of the four kings and released many people from slavery, Lot, Abraham's nephew, included. Amraphael, called also Nimrod ${ }^{32}$ was defeated by Abraham and Eliezer during the „mid-night” - there is a similarity to the description of exodus from Egypt, what also happened during the "mid-night"33), when the Angel of Death passed and killed all the firstborns. PRE reports that thanks to his victory Abraham won great wealth (according

26 Freedman - Simon, The Midrash, XLV:1.

27 Vanderkam, Jubilees, 464.

28 Friedlander, Pirkei, 191.

29 Tb Baba Kama 92a.

30 Friedlander, Pirkei, 193-196.

31 Some rabbis indicate that there are numerological issues also in this case: Abraham's chief servant, Eliezer, and described as his sole heir in Genesis 15:2, has a Hebrew name that adds up to 318 .

32 TB Eruvin 53a, MBR XLII:4.

33 MBR XLIII:3; Ex 12,29. 
Szósta próbą ${ }^{31}$ było zwycięstwo Abrahama nad czterema królami (Rdz 14,1-16), „(gdy) wszyscy królowie wystąpili przeciwko niemu, aby go zabić". Również dzięki interwencji i pomocy Boga Abraham i jego $318^{32}$ uzbrojonych i wyszkolonych wojowników odparło atak czterech królów i wyzwoliło z niewoli wielu ludzi z Kanaanu, w tym Lota, bratanka Abrahama. Amrafel, zwany także Nimrodem ${ }^{33}$ zostaje pokonany przez Abrahama i Eliezera podczas „,pół-nocy” - występuje tutaj podobieństwo do opisu wyjścia z Egiptu, co również nastąpiło podczas ,pół-nocy” ${ }^{34}$, kiedy to anioł zabił wszystkich pierworodnych. Midrasz PRE relacjonuje, że dzięki swemu zwycięstwu Abraham zdobył majątek (według relacji Hillela Starszego) i oddał jako pierwszy dziesięcinę Szemowi synowi Noego (Abraham zapoczątkował oddawanie dziesięciny): „Wziął całą dziesięcinę królów i całą dziesięcinę z majątku Lota, syna swego brata, i dał Szemowi, synowi Noego, jak jest powiedziane: „I dał mu dziesiątą część wszystkiego”. Nie ma w tekście midraszowym bezpośredniej wzmianki o królu Melchizedeku, ale PRE jest zgodne w przypisach z tradycją rabiniczną co do tego, że Szem jest identyfikowany z Melchizedekiem (por. KJ 13.25). Według relacji PRE Abraham wychwala Boga: „Władco wszystkich światów! Nie pokonałem ich (królów) przez moc mojej ręki, ani mocy mojej prawej ręki, którą uczyniłem wiele rzeczy, ale poprzez moc Twojej ręki, Ty będziesz moją tarczą na tym świecie, jak i świecie, który dopiero nadejdzie”. Dalej PRE cytuje Ps 3,3: „Ale Ty, Panie, jesteś dla mnie tarczą".

Siódma próba to przymierze „dwóch połówek” - B'rit Bein HaBetharim (Rdz 15,1-18) ${ }^{35}$. Trzeba wskazać, że Abraham w siódmej próbie doświadczył jednego z najważniejszych przymierzy z Bogiem,

\footnotetext{
31 Friedlander, Pirkei, 193-196.

32 Raszi (w Komentarzu do Ks. Rodzaju), powołując się na tradycję, uważa, że zwycięstwo było zasługą samego Eliezera, sługi Abrahama: „Nasi Mędrcy powiedzieli, że był to sam Eliezer, a liczba 318 reprezentuje gematrię (wartość liczbową) jego imienia”.

33 TB Eruvin 53a, MBR XLII:4

34 MBR XLIII:3; Wj 12,29

35 Friedlander, Pirkei, 197-202.
} 
to account of Hillel the Elder) and as the first one provided a tithe to Shem, son of Noah (Abraham was the first to begin to give a tithe. He took all the tithe of the kings and all the tithe of the wealth of Lot, the son of his brother, and gave (it) to Shem, the son of Noah, as it is said, „And he gave him a tenth of all"). Also, in this midrashic text there is no direct mention of king Melchizedek, however, in this respect PRE is conform (in the footnotes) that Shem shall be identified with Melchizedek (see: BJ 13.25). Pursuant to PRE Abraham praises God: Sovereign of all worlds ! Not by the power of my hand, nor by the power of my right hand have I done all these things, but by the power of Thy right hand with which Thou dost shield me in this world and in the world to come, as it is said" later he quotes Ps. 3,3 „But thou, O Lord, art a shield about me".

The seventh trial is a Covenant of the Parts - Brit Bein HaBetharim (Gen. 15,1-18) ${ }^{34}$. In this seventh trial Abraham experienced one of the most significant covenants with God, as it was the covenant unto "life and death". It has to be mentioned that the interpretation of the „flaming torch" (smoking furnace) in Gen. 15,17, passing between the pieces of animals ${ }^{35}$ was interpreted by rabbi Ze'er (most likely Azariah) with use of an example taken from Is. 31,9: „the LORD, whose fire is in Zion, and his furnace in Jerusalem” what suggests the constant presence of God in Jerusalem. It is also indicated that Isaiah, as well as probably other prophets believed in the power of the eternal covenant B'rit Bein HaBetarim, whose time, duration and validity have no end date - it remains in force until the times of arrival of King Messiah.

The eight trial ${ }^{36}$ occurred when Abraham was 99 years old and he performed the rite of B'rit Mila (Gen. 17,24-27), i.e. the circumcision of the foreskin flesh of himself, Ishmael and all the male servants ${ }^{37}$

\footnotetext{
34 Friedlander, Pirkei, 197-202.

35 MBR, XLIV:21.

36 Friedlander, Pirkei, 203-214.

37 PRE xxi, MBR XLVI:4 and XLVII:8.
} 
bo było ono przymierzem na „śmierć i życie”. Należy wspomnieć, że interpretacja ,płomienia” (gorącego pieca) w Rdz 15,17, przechodzącego pośród połówek zwierząt ${ }^{36}$ została zinterpretowana przez rabbiego Ze'era (prawdopodobnie Azariah) z użyciem przykładu zaczerpniętego z wersetu Iz 31,9: „Wyrocznia Pana, który ma ogień na Syjonie i piec swój w Jeruzalem" - co sugeruje stałą obecność Boga w Jerozolimie. Wskazuje się także, że Izajasz, jak i prawdopodobnie inni prorocy wierzyli w moc wiecznego przymierza $B$ 'rit Bein HaBetarim, którego czas i okres nie ma końcowej daty - obowiązuje ono aż do czasów nadejścia Mesjasza Króla.

Ósma próba ${ }^{37}$ nastąpiła według rabinów wtedy, gdy w wieku 99 lat Abraham dokonał obrzędu B'rit Mila (Rdz 17,24-27), czyli obrzezania napletka sobie, Izmaelowi i całej swej męskiej służbie ${ }^{38} \mathrm{w}$ dniu Jom Kippur - siódmego miesiąca Tiszri. Inne źródła podają, że miało to miejsce w Rosz Haszana lub nawet w święto Pesach ${ }^{39}$. PRE cytuje Iz 52,1: „Oblecz się w szaty najokazalsze, o Święte Miasto, Jeruzalem! Bo już nie wejdzie nigdy do ciebie żaden nieobrzezany ani nieczysty". Wyjaśnia także dalej, że:

napletek jest hańbą, jak jest powiedziane: „Albowiem byłoby to dla nas hańbą" (Rdz 34:14), ponieważ napletek jest bardziej nieczysty niż wszystkie nieczyste rzeczy, jak jest powiedziane: ,już nie wejdzie nigdy do ciebie nieobrzezany ani nieczysty" (Iz 52,1). Bo napletek jest skazą ponad wszelkie skazy. Obrzezaj ciało swojego napletka i bądź doskonały.

Według jednej z tradycji żydowskich, obrzezania Abrahama dokonał Szem, syn Noego. Rabban Gamaliel - syn rabbiego Jehudy HaNasi, powiedział: „Abraham posłał po Szema, (który urodził się już

\footnotetext{
36 MBR, XLIV:21

37 Friedlander, Pirkei, 203-214.

38 MBR XLVI:4 oraz XLVII:8

39 TB Baba Mezia 86b, KJ 34.18.
} 
on the day of Yom Kippur ${ }^{38}$, the seventh day of the month Tishri. Other sources provide for that it took place on Rosh HaShana or over during the Passover time ${ }^{39}$. PRE quotes in this respect the phrase from Is. 52,1: ,put on thy beautiful garments, O Jerusalem, the holy city: for henceforth there shall no more come into thee the uncircumcised and the unclean". It also explains that:

the foreskin is a reproach, as it is said, "For that is a reproach unto us" (Gen. 34:14), because the foreskin is more unclean than all unclean things, as it is said, "For henceforth there shall no more come into thee the uncircumcised and the unclean" (Is. 52:1). For the foreskin is a blemish above all blemishes. Circumcise the flesh of thy foreskin and be perfect.

According to one of the many Jewish traditions, as presented in PRE, the circumcision of Abraham was performed by Shem, the son of Noah. Rabban Gamaliel - the son of Rabbi Jehudah HaNasi (the Prince), said in PRE 29.2: „Abraham sent and called for Shem, the son of Noah" (who was born circumcised) for to perform the rite of B'rit Milah - the circumcision of Abraham, Ishmael and the male servants. It has to be explained that pursuant to rabbinic tradition (it is accounted for in detail in the MBR), the long-lived Shem is identical to biblical king of Salem (Jerusalem), called Melchizedek the Righteous King. It may be asked: if Shem were circumcised and knew the B'rit Milah rite, opening the gates of God's blessings, why he had waited until that time to convince Abraham? Abraham had been living in Canaan for 24 years then. Until his circumcision in the year 2039, there were numerous other Shem's relatives still alive, not only Shem himself, but also Serug (d. in 2049), Arpachshad (d. in 2096), Shelah (d. in 2126) and Eber as the last of Shem's lineage (d. in 2187). MBR does not mention Shem as mohel, circumcising Abraham and

\footnotetext{
38 PRE xxi,2.

39 TB Baba Mezia 86b, BJ 34.18.
} 
obrzezany), aby dokonał procesu B'rit Mila - obrzezania Abrahama, Ismaela i jego męskiej służby”. Trzeba tutaj wyjaśnić, że według tradycji rabinicznej (o czym opowiada MBR) długowieczny Szem jest tożsamy z biblijnym królem Salemu (Jerozolimy) i nazywa się Melchizedek - Król Sprawiedliwy. Można zadać pytanie: jeśli Szem był obrzezany i znał proces B'rit Mila, który otwiera bramy do Bożych błogosławieństw, dlaczego czekał aż do tego czasu, aby przekonać Abrahama? Abraham przebywał w Kanaanie już od 24 lat. Do czasu obrzezania Abrahama w 2039 r., poza Szemem, żył jeszcze Serug (zm. w 2049 od czasów Adama), Arpachshad (zm. w 2096), Szelach (zm. w 2126) oraz Eber jako ostatni z linii Szema (zm. w 2187). MBR nie wspomina Szema jako pełniącego rolę mohela, obrzezującego Abrahama i całą jego męską rodzinę, a powstał przecież ok. 600 lat wcześniej niż PRE. Można więc sądzić, że historia obrzezania Abrahama przez Szema, jak podaje PRE, może być fikcją literacką, a wzmianka o nim jako realizującym B’rit Mila, miała podkreślić prestiż i doniosłość samego obrzędu. Wg PRE 29.2, jak mówi rabbi Gamaliel, rytuał odbył się w samo południe, dziesiątego dnia Tiszri, siódmego miesiąca w Jom Kippur:

W tym samym dniu, który (to znaczy) w pełni słońca w południe. Wszyscy ci, którzy zostali obrzezani, mieli (nadmierny) ból trzeciego dnia (jak skomentował rabin Hanina ben Dosa), jak to jest powiedziane: „I to stało się trzeciego dnia, kiedy byli chorzy". Tego trzeciego dnia po obrzezaniu, kiedy Abraham był jeszcze bardzo obolały (Rdz 34,25), spotkał Boga i Jego aniołów (Rdz 18,1) „Święty, niech będzie błogosławiony i aniołowie zstąpili, aby odwiedzić naszego ojca Abrahama", jak się mówi: "I ukazał mu się Pan”.

Dziewiąta próba ${ }^{40}$ - w myśl PRE - obejmuje podjęcie decyzji przez Abrahama o wygnaniu Hagar wraz z Izmaelem (Rdz 21,12-14).

40 Friedlander, Pirkei, 203-214. 
his entire male family and yet it originated before PRE. Thus it may be assumed that the story of circumcising Abraham by Shem as it is provided in the PRE is a work of fiction, and such a mention of him performing the rite was supposed to highlight the significance and importance of the rite itself. Pursuant to PRE 29.2, as rabbi Gamaliel reports, the rite took place:

In the selfsame day which (means) in the might of the sun at midday. All those, who were circumcised had (excessive) pain on the third day (as Rabbi Hanina ben Dosa commented), as it is said, "And it came to pass on the third day, when they were sore". On that third day following circumcision, when Abraham was still very sore, (Gen 34,25), he met God and His ministering angels (Gen 18,1) - "The Holy One, blessed be He, and the angels descended to visit our father Abraham", as it is said, "And the Lord appeared unto him".

The ninth trial ${ }^{40}$ - in accordance with PRE - regards the making the decision by Abraham to cast out Hagar and Ishmael (Gen. 21,12-14). Ishmael was 17 at that time (pursuant to Venice PRE manuscript he was 27$)^{41}$. The account contained in PRE clearly confirms that Hagar was Abraham's wife, and not just a handmaid, servant, as Abraham wrote her a bill of divorce and gave her brad and water: he sent her and her son away from himself, and from Isaac his son, from this world and from the world to come, as it is said: „And Abraham rose up early in the morning, and took bread and a bottle of water" (Gen. 21:14). He sent her away with a bill of divorcement, and he took the veil, and he bound it around her waist, so that it should drag behind her to disclose (the fact) that she was a bondwoman. The divorce occurred by Hagar's fault, thus she was not entitled to any severance, such as in the case of Sarah being sent away by the pharaoh or by Abimelech. Further

\footnotetext{
40 Friedlander, Pirkei, 203-214.

41 Friedlander, Pirkei, 216.
} 
Izmael miał wtedy 17 lat (według manuskryptu PRE z Wenecji, miał 27 lat ${ }^{41}$. Relacja zawarta w PRE wskazuje, że Hagar była żoną Abrahama, ponieważ znajduje się tam wzmianka, że Abraham napisał list rozwodowy dla Hagar oraz dał jej chleb i wodę. Rozwód nastąpił z winy Hagar, więc nie należała się jej odprawa, jak miało to miejsce w przypadku odprawienia Sary przez Faraona lub Abimelecha. Dalej znajdziemy relację, że po śmierci Sary, Abraham odnalazł Hagar i ponownie ożenił się z nią jako trzecią żoną ${ }^{42}$. Była ona wówczas zwana Keturą - jest to imię oznaczające zapach, kadzidło:

po śmierci Sary, Abraham ponownie wziął (Hagar) swoją rozwiedzioną (żonę), jak jest powiedziane: ,A Abraham ponownie pojął żonę, a jej imię było Ketura” (Rdz 25:1). Dlaczego jest napisane „I on znowu”? Bo za pierwszym razem była jego żoną, a on znów się do niej polubił. Miała na imię Ketura, ponieważ była perfumowana wszelkiego rodzaju zapachami.

Bóg zatwierdził tę próbę, ponieważ wspólne życie Izmaela i Izaaka koliduje zarówno z przyszłymi planami Bożymi, jak i oczekiwaniami Abrahama.

Dziesiąta, kulminacyjna próba ${ }^{43}$ to Akeda Izaaka (Rdz 22,1-16) na Górze Moria (inni nazywają ją także górą Syjon, opisywana jest także

41 Friedlander, Pirkei, 216.

42 Tannaici nie są zgodni co do tożsamości Ketury. Według jednego z poglądów Abraham ożenił się ponownie po śmierci Sary i miał w sumie w ciągu swojego zycia trzy żony: Sarę, Hagar i Keturę. Inna tradycja utożsamia Keturę z Hagar i dlatego wg tej tradycji Abraham ożenił się tylko dwa razy. Mianowicie, Raszi wprost sugeruje, że Ketura to Hagar: „Nazywano ją Ketura, ponieważ jej czyny były tak przyjemne jak kadzidło i ponieważ zawiązała swój otwór [wyjaśnienia wyłaniające się z dwóch rabinicznych etymologii ludowych dotyczących jej imienia]; od dnia, w którym opuściła Abrahama, nie łączyła się z żadnym mężczyzną". Targum Yonatan, przekład/komentarz aramejski przypisywany Yonatanowi ben Uzielowi, jeszcze mocniej sugeruje, że była to Hagar: „Była Hagar, która była z nim związana od samego początku".

43 Friedlander, Pirkei, 223-230 
the information is provided that following Sarah's death Abraham found Hagar and remarried her as his third wife ${ }^{42}$. She was then called Keturah - this name means fragrance, incense:
after the death of Sarah, Abraham again took (Hagar) his divorced (wife), as it is said, ,And Abraham again took a wife, and her name was Keturah" (Gen. 25:1). Why does it say „And he again”? Because on the first occasion she was his wife, and he again betook himself to her. Her name was Keturah, because she was perfumed with all kinds of scents".

God approved this trial because Ishmael and Isaac's life together would collide both with the prospective God's plans as well as with own Abraham's expectations.

The tenth trial, being a climax of Abraham's experiences ${ }^{43}$ was binding (Akedah) of Isaac (Gen. 22,1-16) on Mount Moriah (some call it Mount Zion, it is also described as zophim - watchers). Account provided in PRE is practically consistent with the MBR, except for the fact that (due to the time of redaction) different rabbis comment and participate in the debate. Rabbi Zechariah indicates that the ram offering on Mount Moriah took place exactly at twilight on Shabbat.

The outcome of Akedah was confirmation that Abraham was able to sacrifice to God everything he had, including his son Isaac.

42 The Tannaim disagree with regard to Keturah's identity. According to one view, Abraham remarried after the death of Sarah and had a total of three wives: Sarah, Hagar, and Keturah. Another tradition identifies Keturah with Hagar, and thus Abraham married only twice. Namely, Rashi boldly suggests that Keturah is Hagar: "She was called Keturah because her deeds were as pleasing as incense and because she tied up her opening [explanations emerging from two rabbinic folk etymologies on her name]; from the day she left Abraham, she did not couple with any man." Targum Yonatan, an Aramaic translation/commentary that is attributed to Yonatan ben Uziel, makes an even stronger statement to suggest that she was Hagar: "She was Hagar, who was bound to him from the start".

43 Friedlander, Pirkei, 223-230. 
jako zophim - strażnica, wieża strażnicza). Relacja z tego zdarzenia przedstawiona w PRE praktycznie pokrywa się z MBR, oprócz tego, że jako komentatorzy i współautorzy dyskusji w PRE występują inni rabini (z racji czasu redakcji PRE). Rabbi Zecheriasz twierdzi, że ofiara z barana na górze Moria odbyła się dokładnie o zmierzchu w szabat.

Wynikiem tego zdarzenia (Akedy) jest potwierdzenie, że Abraham był zdolny poświęcić Bogu wszystko, nawet swojego syna Izaaka. Komentarz PRE pozwala wniknąć w obawy Abrahama, błagającego Boga, aby już więcej nie poddawał go żadnym próbom, gdyż ta ostatnia była dla niego najgorsza. Rabini w PRE wnioskują z opisu Akedy, że wszystkie błogosławieństwa od Boga dostajemy zawsze z ,zasługi modlitwy”. Rabbi Izaak cytuje Rdz 22,5: „Zostańcie tutaj z osłem, a ja i chłopiec pójdziemy tam, aby oddać pokłon Bogu, a potem wrócimy do was”, a także Ps 99,5: „Wysławiajcie Pana, Boga naszego, oddajcie pokłon u podnóżka stóp Jego; On jest święty". Wypada podkreślić, że zarówno tłumaczenie polskie w BTP („,oddać pokłon”), jak i inne przekłady, np. ten z BW (,,pomodlimy się") ${ }^{44}$ nie odzwierciedlają w pełni głębi i sensu oryginalnego sformułowania; hebrajskie wyrażenie szacha ma bowiem znacznie głębsze znaczenie, podkreślające postawę szczególnego uniżenia i służebności wobec autorytetu i potęgi Najwyższego ${ }^{45}$.

Listę prób zawartą w PRE w całości i bez modyfikacji przyjmuje Raszi. Z kolei uczeni tacy jak np. Majmonides oraz Josef Hayyoun ${ }^{46}$

44 Biblia Warszawska: Zostańcie tutaj z osłem, a ja i chłopiec pójdziemy tam, a gdy się pomodlimy, wrócimy do was.

45 Jak wyjaśnia to pojęcie The Complete Word Study Dictionary: Old Testament (CWSD, 2003, 1119), czasownik ten oznacza m. in. kłaniać się, paść na twarz, korzyć się, paść, ale także pokornie błagać, okazywać szacunek, adorować, uwielbiać. Pojęcie to wykorzystywane jest by określić pokłon przed monarchą lub innym zwierzchnikiem i oddanie mu hołdu. W BH wykorzystywane np. w Psalmach by oddać szczególność postawy wobec Boga. Por. także: Young’s Literal Translation, https:/www.biblestudytools.com/ylt/.

${ }^{46}$ Ostatni rabin Lizbony przed wygnaniem, XV w., autor wielu orzeczeń prawnych w korespondencji z Abrabanelem, które weszły do traktatu tego ostatniego 
The PRE commentary enables to empathize with Abraham's concerns, pleading God not to put him [Abraham] on any more trials, as the last one was the most difficult and terrifying.

The rabbis in PRE infer from the description of Akedah that all the blessings from God come always for the "merit of prayer" Rabbi Isaac quotes Gen 22,5: , Abide ye here with the ass; and I and the lad will go yonder and worship, and come again to you.", as well as Ps. 99,5: ,Exalt ye the LORD our God, and worship at his footstool; for he is holy". It should be stressed that neither translation (,worship", „bow yourself ${ }^{44}$ ") do not fully reflect the profundity and the actual sense of the original word; the Hebrew expression shakcha has yet a deeper meaning, emphasizing the specific humility, humbleness and servitude with respect to the authority and power of the Almighty ${ }^{45}$.

The list of trials, as presented above in line with the contents of PRE has been fully and without any alterations accepted by Rashi. On the other hand the scholars such as Maimonides and Joseph Hayyoun $^{46}$ (in the commentary to PRE - Millei de-Avot) modify this description. Maimonides ${ }^{47}$ lists the trials as follows:

1. God tells Abraham to leave his homeland to become a stranger in the land of Canaan;

2. Upon arrival to Canaan, Abraham and his tribe experience a famine that forces them to leave to Egypt;

\footnotetext{
44 Young's Literal Translation, https:/www.biblestudytools.com/ylt/.

45 Pursuant to the explanation contained in The Complete Word Study Dictionary:
} Old Testament (CWSD, 2003, 1119), this verb means, among others, to bow down, to prostrate oneself, to crouch, to fall down, to humbly beseech, to do reverence, to worship. The primary meaning is to bow down. It is used to indicate bowing before a monarch or a superior and paying homage to him/her. In the Hebrew Bible it has been used e.g. in Psalms to describe the peculiarity of the attitude towards God.

46 Th last Chief rabbi of Lisbon prior to the Expulsion, lived in the XV century, author of numerous legal rulings contained in his correspondence with Abravanel, included into the latter's treatise Maggid Mishneh, as well as author of many commentaries (Skolick, Encyclopaedia, 8.485).

${ }^{47}$ Commentary to the Mishnah ad loc. 
(w komentarzu do PRE - Millei de-Avot) modyfikują ten opis. Majmonides ${ }^{47}$ wymienia próby w następujący sposób:

1. Bóg mówi Abrahamowi, aby opuścił swoją ojczyznę i stał się obcym w ziemi Kanaan;

2. Po przybyciu do Kanaanu Abraham i jego ludzie doświadczają głodu, który zmusza ich do opuszczenia Egiptu;

3. Egipcjanie chwytają żonę Abrahama, Sarę i przyprowadzają ją do Faraona;

4. Abraham mierzy się z wrogiem w bitwie z królami;

5. Następnie, nie mogąc mieć dzieci z Sarą, postanawia poślubić Hagar;

6. Bóg nakazuje Abrahamowi obrzezać się w podeszłym wieku;

7. Król Geraru Abimelech odbiera Sarę Abrahamowi, chcąc ją zabrać dla siebie;

8. Bóg nakazuje Abrahamowi odesłać Hagar wraz z dzieckiem, które z nią miał;

9. W wyniku wygnania Hagar, syn Abrahama, Imzael, zostaje odsunięty od świata;

10. Bóg nakazuje Abrahamowi złożyć Izaaka na ołtarzu.

Z drugiej strony, jak już wspomniano, Raszi, w pełni podążając za PRE, włącza do listy testów, którym poddano Abrahama pewne zdarzenia, które są odnotowane tylko w midraszach i wymienia następujące próby:

1. Abraham ukrywa się w podziemnej jaskini przez trzynaście lat w Ur Chaldejczyków, kiedy król Nimrod próbował go zabić (Midrasz ha-Gadol, Genesis 11:28);

2. Nimrod wrzuca Abrahama do ognistego pieca za nieczczenie bożków (Eruvin 53a, Pesachim 118a, Bereszit Rabba 38:13 $\mathrm{i}$ in.);

3. Abraham otrzymuje polecenie opuszczenia swojej ojczyzny i rodziny $(\mathrm{Rdz} 12,1)$;

Maggid Mishneh, autor wielu komentarzy (Skolick, Encyclopaedia, 8.485).

47 Komentarz do Miszny ad loc. 
3. The Egyptians seize Abraham's wife, Sarah, and bring her to Pharaoh;

4. Abraham faces incredible odds in the battle against the kings;

5. Subsequently, after not being able to have children with Sarah, he decides to marry he Hagar;

6. Abraham is ordered b God to circumcise himself at an advanced age;

7. The king of Gerar, Abimelech, captures Sarah, intending to take her for himself;

8. God orders Abraham to send Hagar away together with a child he had with her;

9. In consequence of expulsion of Hagar, Abraham's son, Ishmael, becomes estranged;

10. God commands Abraham to sacrifice Isaac upon an altar.

On the other hand, as already mentioned, Rashi, fully following PRE, includes to the list of trials certain events which are recorded only in the Midrashim and enumerates the following trials:

1. Abraham's hiding in an underground cave for thirteen years in Ur of the Chaldees, when the king Nimrod sought to kill him (Midrash ha-Gadol, Genesis 11:28);

2. Nimrod casts Abraham into a fiery furnace for not worshipping idols (Eiruvin 53a, Pesachim 118a, Bereishit Rabbah 38:13 et. al.);

3. Abraham receives the command to leave his homeland and family (Genesis 12:1);

4. Experience of the famine in Israel which began as soon as Abraham arrived (v.10);

5. Taking Sarah by the Egyptians at the order of the Pharaoh (v.14-15);

6. Capturing of Abraham's nephew Lot in the war of the four kings against the five, as a result of which Abraham went to war to rescue him (14:1-16);

7. G-d's foretelling that Abraham's descendants would be enslaved and oppressed (15:13-16) 
4. Doświadczenie głodu w Izraelu, który rozpoczął się zaraz po przybyciu Abrahama (w.10);

5. Zabranie Sary przez Egipcjan na polecenie faraona (w. 14-15);

6. Pojmanie Lota, bratanka Abrahama w wojnie czterech królów, w wyniku której Abraham wyruszył na wojnę, aby go uratować (w. 14:1-16);

7. Przepowiednia Boga, że potomkowie Abrahama będą zniewoleni i uciskani (w. 15:13-16)

8. Obrzezanie Abrahama i jego syna w wieku dziewięćdziesięciu dziewięciu lat (w. 17:24);

9. Wypędzenie Ismaela i Hagar;

10. Akeda.

Lista dziesięciu prób Abrahama sporządzona przez rabina Ovadię Bartinurę jest podobna do listy Rasziego; jednak pomija trzynaście lat spędzonych na ukrywaniu się przed Nimrodem i uwzględnia porwanie żony Abrahama przez Abimelecha (Rdz 20:1-14). Rabin Yonah z Geronah, jak już wspomniano, jest jedynym komentatorem (podobnie jak KJ), który nie wymienia Akedy jako ostatecznego testu i wskazuje na śmierć Sary i konieczność wykupienia dla jej miejsca pochówku ( $\mathrm{Rdz} 23)$ jako ostatnią próbę.

Poniższa tabela podsumowuje omówione powyżej zagadnienia, w tym wybór zdarzeń uznanych za próby i ich kolejność.

Tab. 1. Dziesięć prób Abrahama

\begin{tabular}{|c|c|c|c|}
\hline & Pirke deRabbi Elieser/ Raszi & Księga Jubileuszy & Majmonides \\
\hline 1. & $\begin{array}{l}\text { Ocalenie Abrahama przed } \\
\text { śmiercią na rozkaz Nimroda } \\
\text { i ukrycie się w jaskini }\end{array}$ & & Lech lecha \\
\hline 2. & $\begin{array}{l}\text { Uwięzienie, wrzucenie do } \\
\text { ognistego pieca, ocalenie }\end{array}$ & & $\begin{array}{l}\text { Głód w Kanaanie } \\
\text { i wymarsz do Egiptu }\end{array}$ \\
\hline 3. & Lech lecha & Lech lecha & $\begin{array}{l}\text { Sara zabrana do } \\
\text { Faraona }\end{array}$ \\
\hline 4. & $\begin{array}{l}\text { Głód w Kanaanie i wymarsz } \\
\text { do Egiptu }\end{array}$ & $\begin{array}{l}\text { Głód w Kanaanie i wy- } \\
\text { marsz do Egiptu }\end{array}$ & Wojna z królami \\
\hline 5. & Sara zabrana do Faraona & $\begin{array}{l}\text { Zwycięstwo i uzyskanie } \\
\text { bogactw od królów }\end{array}$ & Małżeństwo z Hagar \\
\hline
\end{tabular}


8. Circumcision of Abraham and his son at the age of ninetynine (17:24);

9. Expelling Ishmael and Hagar;

10. The Akedah.

Rabbi Ovadiah of Bartinura's listing of Abraham's ten trials is similar to Rashi's; however he omits the thirteen years spent hiding from Nimrod, and includes the Abimelech's abduction of his wife (Genesis 20:1-14). Rabbi Yonah of Geronah, as previously mentioned, is the only commentator (similarly to BJ) who does not list the Akedah as the final test and indicates the death of Sarah, and having to buy her burial plot (Genesis 23) as the last trial.

The table attached below summarises the issues discussed above, including the selection of events regarded as trials and their order.

Tab. 1. Abraham's ten trials

\begin{tabular}{|c|c|c|c|}
\hline & Pirke deRabbi Elieser/ Rashi & Book of Jubilees & Maimonides \\
\hline 1. & $\begin{array}{l}\text { Saving Abraham from death } \\
\text { ordered by Nimrod by hiding } \\
\text { in the cave }\end{array}$ & & Lech lecha \\
\hline 2. & $\begin{array}{l}\text { Imprisonment, casting into } \\
\text { furnace and salvation }\end{array}$ & & $\begin{array}{l}\text { Famine in Canaan and } \\
\text { departing to Egypt }\end{array}$ \\
\hline 3. & Lech lecha & Lech lecha & Taking Sarah to Pharaoh \\
\hline 4. & $\begin{array}{l}\text { Famine in Canaan and depar- } \\
\text { ting to Egypt }\end{array}$ & $\begin{array}{l}\text { Famine in Canaan } \\
\text { and departing } \\
\text { to Egypt }\end{array}$ & War with the kings \\
\hline 5. & Sarah taken to Pharaoh & $\begin{array}{l}\text { Victory and wealth } \\
\text { obtained from } \\
\text { the kings }\end{array}$ & Marriage to Hagar \\
\hline 6. & $\begin{array}{l}\text { Capturing of Lot, war with } \\
\text { the kings and victory over } \\
\text { them }\end{array}$ & $\begin{array}{l}\text { Sarah taken } \\
\text { to Pharaoh }\end{array}$ & Circumcision \\
\hline 7. & $\begin{array}{l}\text { Covenant of the Parts (B'rit } \\
\text { Bein HaBetharim) }\end{array}$ & Circumsion & Taking Sarah by Abimelech \\
\hline 8. & B’rit Milah & $\begin{array}{l}\text { Expelling Hagar } \\
\text { and Ishmael }\end{array}$ & $\begin{array}{l}\text { Order of God to send Hagar } \\
\text { away with her son }\end{array}$ \\
\hline 9. & $\begin{array}{l}\text { Expulsion of Hagar and } \\
\text { Ishmael }\end{array}$ & Akedah & $\begin{array}{l}\text { Expelling Hagar and } \\
\text { Ishmael }\end{array}$ \\
\hline 10. & Akedah & Death of Sarah & Akedah \\
\hline
\end{tabular}




\begin{tabular}{|l|l|l|l|}
\hline & Pirke deRabbi Elieser/ Raszi & \multicolumn{1}{|c|}{ Księga Jubileuszy } & \multicolumn{1}{|c|}{ Majmonides } \\
\hline 6. & $\begin{array}{l}\text { Pojmanie Lota, wojna z kró- } \\
\text { lami i zwycięstwo nad nimi }\end{array}$ & Sara zabrana do Faraona & Obrzezanie \\
\hline 7. & $\begin{array}{l}\text { Przymierze Połówek (B'rit } \\
\text { Bein HaBetharim) }\end{array}$ & Obrzezanie & $\begin{array}{l}\text { Sara zabrana przez } \\
\text { Abimelecha }\end{array}$ \\
\hline 8. & B'rit Milah & Wygnanie Hagar i Izmaela & $\begin{array}{l}\text { Nakaz od Boga aby } \\
\text { odesłać Hagar wraz } \\
\text { z synem }\end{array}$ \\
\hline 9. & Wygnanie Hagar i Izmaela & Akedah & $\begin{array}{l}\text { Wygnanie Hagar } \\
\text { i Izmaela }\end{array}$ \\
\hline 10. & Akedah & Śmierć Sary & Akedah \\
\hline
\end{tabular}

\subsection{Rozumienie prób według MBR}

Dziełem kluczowym dla zrozumienia, jak rabini postrzegali próby, na jakie Bóg postawił Abrahama, jest także Wielki Midrasz (Midrasz HaGadol) do Księgi Rodzaju - Bereszit Rabba ${ }^{48}$. Nawiązania i porównania w zakresie jego treści były wskazywane już wyżej w rozdziale poświęconym PRE. We wstępie do petiha ${ }^{49} 3 \mathrm{w}$ sugghija ${ }^{50}$ XXXII nieznany autor cytuje Psalm 11,5 i wyjaśnia, że:

„Pan bada sprawiedliwego i bezbożnego, A nienawidzi tego, kto kocha bezprawie" (Ps. 11,5). Rabbi Jonatan powiedział: Garncarz nie bada wadliwych naczyń, bo nie może zadać im ani jednego ciosu bez ich rozbicia.

\footnotetext{
48 Freedman - Simon, The Midrash.

49 Petiha, „otwarcie”, to homiletyczne wprowadzenie do danej sekcji tekstu, zgodnie z podziałem czytań Tory w synagodze, w określonej formie i strukturze. Podziały zachowane przez petihy odzwierciedlają trzyletnie cykle odczytów synagogalnych powszechnie występujących w starożytnej Palestynie, w których Tora była czytana w odpowiedniej kolejności przez trzy lata (w przeciwieństwie do tego, trzyletnie podziały używane przez wiele współczesnych synagog polegają na podziale każdej paraszy na trzy części). Petiha zaczyna się wersetem z innego miejsca w Biblii, najczęściej z Księgi Przysłów lub Psalmów. Ten werset zachęca do dyskursu, który ostatecznie znajduje drogę powrotną do pierwszego wiersza czytania tygodniowego z Tory (Jacobs, 2019).

50 Suggija jest częścią Talmudu lub Midraszu, wyodrębnioną osobno do rozważenia w toku dyskusji, myśli i / lub studiów.
} 


\subsection{Understanding of trials in accordance with MBR}

The work of key importance for understanding, how the rabbis perceived the trials God put Abraham to, is also the Great Midrash (Midrash HaGadol) to Book of Genesis - Bereshit Rabbah ${ }^{48}$. In the introduction to petiha 3 in sugghija ${ }^{49}$ XXXII the unknown author quotes the Psalm 11,5 and explains that:

"The Lord trieth the righteous; but the wicked and him that loveth violence His soul hateth" (Ps. XI, 5). R. Jonathan said: A potter does not test defective vessels, because he cannot give them a single blow without breaking them. Similarly the Holy One, blessed be He, does not test the wicked but only the righteous: thus, "The Lord trieth the righteous" R. Jose b. R. Hanina said: When a flax worker knows that his flax is of good quality, the more he beats it the more it improves and the more it glistens; but if it is of inferior quality, he cannot give it one knock without its splitting. Similarly, the Lord does not test the wicked but only the righteous, as it says, "The Lord trieth the righteous". R. Eleazar said: When a man possesses two cows, one strong and the other feeble, upon which does he put the yoke? Surely upon the strong one. Similarly, the Lord tests none but the righteous: hence, "The Lord trieth the righteous".

Based on the text of MBR the conclusion may be drawn that God, until the emergence of Abraham, could not find among all descendants of Shem any person providing God with the assurance of fulfilment of His intentions.

\footnotetext{
48 Freedman - Simon, The Midrash.

49 Suggija is a part of Talmud or Midrash, identified separately for consideration in course of a discussion, thought and/or study.
} 
Podobnie Święty, niech będzie błogosławiony, nie poddaje próbie złych, ale tylko sprawiedliwych: „Pan wypróbowuje sprawiedliwych" R. Jose b. R. Hanina powiedział: Kiedy tkacz wie, że jego len jest dobrej jakości, im mocniej go trze, tym bardziej się poprawia i tym bardziej błyszczy; ale jeśli jest gorszej jakości, nie może uderzyć go jednym uderzeniem bez jego rozszczepienia. Podobnie Pan nie poddaje próbie złych, ale tylko sprawiedliwych, jak mówi: „Pan wypróbowuje sprawiedliwych”. Rabin Eleazar powiedział: Kiedy człowiek posiada dwie krowy, jedną silną, a drugą słabą, na czym kładzie jarzmo? Na pewno na silnym. Podobnie Pan poddaje próbie tylko sprawiedliwych: stąd „Pan wypróbowuje sprawiedliwych".

Na podstawie tekstu MBR można wysnuć wniosek, że Bóg do czasu pojawienia się Abrahama nie mógł znaleźć wśród wszystkich potomków Szema osoby, która dawałaby Bogu pewność spełnienia Jego zamierzeń.

MBR nie opisuje wszystkich prób Abrahama, skupia się tylko na dwóch z nich, przy czym lech lecha (Rdz 12,1) nie została dokładnie opisana jako ,pierwsza” - moment pojawienia się tego wydarzenia wśród wszystkich doświadczeń życiowych Abrahama nie został przesądzony, ale w komentarzu określono je jako „,próbę” ${ }^{51}$. Niewątpliwie jednak ostatni test dotyczący Akedy został wprost wskazany przez rabinów w MBR jako ,dziesiąty" 52 .

Według rabinów nakaz „Wyjdź/idź (naprzód)” zawarty w Rdz 12,1 dotyczył wejścia w pierwszą próbę; podobnie ostatnie polecenie ,idź” w Rdz 22,1 (dotyczące związania Izaaka) było nakazem wejścia w ostatnią próbę. Abraham nigdy się nie wahał i dlatego Bóg wybrał go na Praojca przyszłego Narodu Izraela i całego świata ${ }^{53}$.

\footnotetext{
51 Freedman -Simon, The Midrash, XXXIX:8.7.

52 Freedman -Simon, The Midrash, LVI:1.

53 Freedman -Simon, The Midrash, XXXIX:1.
} 
MBR does not describe all trials of Abraham, it focuses only on two of them, where lech lecha (Gen. 12,1) has not been precisely described as the "first" - the order of appearance of this event among all Abraham's life experiences has not been prejudged, still they described it in the commentary as "trial" 50 . Undoubtedly, however, the last trial regarding Akedah was directly indicated by the rabbis in the MBR as the "tenth"

According to rabbis the commandment ,go (forth)" contained in Gen. 12,1 regarded stepping in to the first trial; similarly the last order "go" in Gen. 22,1 (concerning the binding of Isaac) was the command to step into the last one. Abraham never hesitated and that is why God chose him as the Forefather of the future nation of Israel and of the whole world ${ }^{52}$.

Pursuant to the customs of Abraham's times the care of parents was the duty of the eldest son. When Abraham left to Canaan, his parents were still alive - Terah was 130 and lived thereafter for 75 more years (Gen. 11,32). Abraham, even as the God's chosen one could not just go away and abandon his parents as it would be contrary to the thencustoms. Rabbis in the MBR appropriately explained this issue. MBR shows the fervent discussion of rabbis, who stress the unique righteousness of Abraham in comparison to other inhabitants of his home land. The rabbis explain the relationship between Terah and Abraham in particular way, claiming that Terah was actually ,dead while alive".

„But first you may learn that the wicked [Terah], even during their lifetime, are called dead" 53 . This, in the rabbis' view, exempted Abraham from the obligation of care for parents, as pursuant to their interpretation, those who do not observe the God's Law, are dead while alive and therefore the descendants do not have to care for them - they are released from such a moral duty. God comforted

\footnotetext{
50 Freedman -Simon, The Midrash, XXXIX:8.7.

51 Freedman -Simon, The Midrash, LVI:1.

52 Freedman -Simon, The Midrash, XXXIX:1.

53 Freedman -Simon, The Midrash, XXXIX:7.3.
} 
Zgodnie ze zwyczajami epoki Abrahama opieka nad rodzicami była obowiązkiem najstarszego syna. Kiedy Abraham wyszedł do Kanaanu, jego rodzice jeszcze żyli - Terach miał 130 lat i żył potem jeszcze przez 75 lat (Rdz 11,32). Abraham, nawet jako wybrany przez Boga, nie mógł tak po prostu odejść i porzucić swoich rodziców, ponieważ byłoby to sprzeczne z ówczesnymi zwyczajami. Rabini w MBR odpowiednio wyjaśnili tę kwestię. MBR ukazuje gorącą dyskusję rabinów, którzy podkreślają wyjątkową sprawiedliwość Abrahama w porównaniu z innymi mieszkańcami jego ojczyzny. Rabini w szczególny sposób tłumaczą relację między Terachem a Abrahamem, twierdząc, że Terach w rzeczywistości był „martwy za życia”: „Ale najpierw możesz się dowiedzieć, że niegodziwi [Terach] nawet za życia nazywani są umarłymi" 54 . To, zdaniem rabinów, zwalniało Abrahama z obowiązku opieki nad rodzicami, gdyż według ich interpretacji ci, którzy nie przestrzegają Prawa Bożego, umierają za życia, a zatem potomkowie nie muszą się nimi opiekować - oni są zwolnieni z takiego moralnego obowiązku. Bóg pocieszył Abrahama i zapewnił go, że Patriarcha może odejść i opuścić swoich rodziców bez ryzyka popełnienia błędu ${ }^{55}$. Rabin Abba bar Kahana wyjaśnił, że:

Czyjekolwiek imię zostało powtórzone w ten sposób, ten ma udział na tym świecie i w przyszłym świecie. Wnieśli mu sprzeciw: Ale jest napisane, TERAZ TO SĄ POKOLENIA TERAHA. TERAH ZRODZIŁ ABRAMA, itd.? To też nie obala tego, odpowiedział, bo co to znaczy: Ale ty [Abrahamie] pójdziesz w pokoju do swoich ojców (ib. $\mathrm{XV}, 15)$ ? On [Bóg] poinformował go, że jego ojciec ma udział w przyszłym świecie; Zostaniesz pochowany po osiągnięciu późnej starości (ib.): Poinformował go, że Izmael odpokutuje w swoim czasie.

\footnotetext{
54 Freedman -Simon, The Midrash, XXXIX:7.3.

55 Freedman -Simon, The Midrash, XXXVIII:12.
} 
Abraham and assured him that the Patriarch was free to go and leave his parents without the risk of being misjudged ${ }^{54}$. Rabbi Abba bar Kahana explained that:

Whoever has his name thus repeated has a portion in this world and in the World to Come. They raised an objection to him: But it is written, NOW THESE ARE THE GENERATIONS OF TERAH. TERAH BEGOT ABRAM, etc.? That too does not disprove it, replied he, for what is the meaning of, But thou [Abraham] shalt go to thy fathers in peace (ib. XV, 15)? He [God] informed him that his father had a portion in the World to Come; Thou shalt be buried in a good old age (ib.): He informed him that Ishmael would repent in his own days.

Additional commentary can be also found in the $\mathrm{MBR}^{55}$ to Gen. 22,15-17, where God spoke to Abraham with the mouth of the Angel of the Lord:

By myself have I sworn, saith the LORD, for because thou hast done this thing, and hast not withheld thy son, thine only son That in blessing I will bless thee, and in multiplying I will multiply thy seed as the stars of the heaven, and as the sand which is upon the sea shore; and thy seed shall possess the gate of his enemies.

MBR provides for an account of the Abraham's response, which may sound very surprising. Abraham begs that this trial shall be the last one and that he is no more put on further trials: "He had begged Him [Angel of the Lord]: Swear to me not to try me again henceforth, nor my son Isaac. (...)". This plea indicates that - as it was later interpreted by Samuel ben Meir (Rashbam) - this trial

\footnotetext{
54 Freedman -Simon, The Midrash, XXXVIII:12.

55 Freedman -Simon, The Midrash, LVI:11.
} 
W MBR można też znaleźć dodatkowy komentarz do Rdz 22,15-1756, gdy Bóg przemówił do Abrahama ustami Anioła Pańskiego:

Przysiągłem na siebie samego, mówi Pan: Ponieważ to uczyniłeś i nie wzbraniałeś się ofiarować mi jedynego syna swego. Będę ci błogosławił obficie i rozmnożę tak licznie potomstwo twoje jak gwiazdy na niebie $\mathrm{i}$ jak piasek na brzegu morza, a potomkowie twoi zdobędą grody nieprzyjaciół swoich.

MBR zawiera opis reakcji Abrahama na tę obietnicę, który może brzmieć bardzo zaskakująco. Abraham błaga, aby ta próba była ostatnią i żeby nie był już wystawiany na dalsze próby: „Błagał Go [Anioła Pańskiego]: ,Przysięgnij mi, że odtąd nie będziesz mnie doświadczał, ani mojego syna Izaaka. (...)”. To błaganie wskazuje, że - jak później interpretował Samuel ben Meir (Raszbam) - ta próba była również karą Bożą. W świetle relacji MBR Abraham poważnie zmagał się z tym testem ${ }^{57}$. Według tej interpretacji dziesiąta próba była karą Bożą - zamierzonym ,zadawaniem bólu” za zobowiązanie, jakie (wbrew woli Bożej) Abraham złożył królowi Abimelechowi (Rdz 21,23n). Abraham przysiągł królowi Abimelechowi, że ani on, ani jego potomkowie nigdy nie zostaną wygnani z ziemi Kanaan. Tymczasem Bóg (w Rdz 15,7) przysiągł i obiecał Abrahamowi i jego potomkom cały Kanaan. Tym samym przymierze między Abrahamem a Abimelechem było sprzeczne z wolą Najwyższego: Abraham i jego potomkowie mieli otrzymać „całość Kanaan”, a nie tylko jego część. Raszbam podjął się w tym kontekście analizy słowa nisah z Wj 17,7 - czasownika, który, jak wskazał, może w tym kontekście oznaczać nie tylko próbę lub test, ale także rozpacz - uczucie, którego Abraham bardzo mocno doznał, składając swego syna Izaaka na całopalną ofiarę. Utrata syna to brak dziedzica i śmierć rodziny. Wiekuisty niemal natychmiast ukarał

\footnotetext{
56 Freedman -Simon, The Midrash, LVI:11

57 Freedman -Simon, The Midrash, LVI:11.
} 
was also God's punishment. In light of the MBR's account Abraham seriously struggled with this trial ${ }^{56}$. According to this interpretation the tenth trial was God's punishment - intended "pain infliction" for the commitment Abraham made to king Abimelech (Gen. 21,23n). Abraham swore to the king that neither him or his descendants would ever be expelled from the land of Canaan. Meanwhile, God (in Gen. 15,7) swore and promised he entire Canaan to Abraham and his descendants, thus the covenant between Abraham and Abimelech was contrary to the wish of the Highest: Abraham and his descendants were supposed to receive the "entire" Canaan and not only a part thereof. Rashbam in this context took on the analysis of the word nisah from Ex. 17,7 - the verb, which, as he indicated, in this context may signify not only the trial and/or test, but also despair - the feeling Abraham experienced very strongly offering his son Isaac for the burnt sacrifice. The loss of a son is lack of the heir and death of the family. The Eternal almost immediately punished Abraham for his thoughtless action. Abraham humbly accepted the "death sentence" for Isaac, meaning the end of succession. By that for the last time - in the tenth trial - he proved his allegiance and faith in God.

By way of the discussions as above-referred the rabbis tried to explain the reasons for each trial, indicating in particular the peculiarities of the Abraham's character and his special bond with the Eternal.

\section{SUMMARY}

Accounting for the history of Abraham as a series of ten trials has existed since the very beginning of the known interpretations of the Book of Genesis. Already the oldest sources such as BJ and/ or PA at least make mention of the trials. Such a presentation of the Patriarch's figure was intended to provide the theological foundations for the choice of that particular man (and none other)

56 Freedman -Simon, The Midrash, LVI:11. 
Abrahama za jego bezmyślne działanie i niepotrzebną obietnicę. Abraham pokornie przyjął „wyrok śmierci” na Izaaka, co oznaczało koniec sukcesji. Tym samym po raz ostatni - w dziesiątej próbie - udowodnił swoją wierność i wiarę w Boga. Poprzez dyskusję w MBR, o której mowa powyżej, rabini starali się wyjaśnić powody każdego testu, wskazując w szczególności na szczególne cechy charakteru Abrahama i jego szczególną więź z Przedwiecznym.

\section{PODSUMOWANIE}

Relacjonowanie historii życia Abrahama jako serii dziesięciu prób istnieje od samego początku znanych interpretacji Księgi Rodzaju. Już najstarsze źródła, takie jak KJ i PA, przynajmniej wspominają o dziesięciu próbach. Takie przedstawienie postaci Patriarchy miało stanowić teologiczne podstawy wyboru tego konkretnego człowieka (i nikogo innego) dokonanego przez Boga. Jak opisano powyżej, nie ma jednej, jednolitej listy takich prób, a źródła rabiniczne różnią się co do wyboru wydarzeń określanych jako próby i ich kolejności. Koncepcje oparte są na tekście Biblii Hebrajskiej, ale także innych źródłach i tradycji.

Wspólne dla wszystkich tych rozważań jest to, że historia Abrahama, według rabinów, była przez wieki nieustannym, nieustannym odkupieńczym aktem Boga dla zbawienia i wyzwolenia Żydów. Idea przymierza z Bogiem ( $b$ 'rit) począwszy od Abrahama Avinu jest fundamentem, kamieniem węgielnym judaizmu: Izrael zawarł przymierze z Bogiem - porozumienie obejmujące prawa i obowiązki obu stron. Abraham musiał zostać poddany dziesięciu próbom wiary, aby udowodnić, że jest godzien znieść dar wiecznego przymierza z Bogiem.

Według Majmonidesa słowa „Bóg wypróbował Abrahama” nie oznaczają, że Bóg go wypróbował, ale uczynił Abrahama przykładem skrajnych granic miłości i bojaźni względem Boga. „Teraz wiem, że boisz się Boga" (Rdz 22,12) oznacza, że Bóg oznajmił całej ludzkości, jak daleko musi zajść człowiek w bojaźni wobec Wszechmogącego. Według Nachmanidesa Akeda jako ostatnia próba skupia się na pogodzeniu uprzedniego poznania Boga z wolną wolą człowieka. Bóg wiedział, jak zachowa się Abraham, ale z punktu widzenia Abrahama 
made by God. As described above, there is no single list of such trials and the rabbinical sources vary as to the choice of events determined as trials and their order. The concepts are based on the text of Hebrew Bible, but also other sources and tradition.

What is common for all these considerations, it is that the history of Abraham, according to rabbis has been the relentless, continuous redemptive act of God, for the sake of salvation and liberation of the Jews throughout the centuries. The idea of the covenant with God (b'rit) starting from Abraham Avinu, is a foundation, a cornerstone of Judaism: Israel entered into the covenant with God - an agreement comprising of rights and duties of both parties. Abraham had to be put to ten trials of his faith for the sake of proving his worthiness to stand the gift of Godly eternal covenant.

According to Maimonides, the words „God tried Abraham” do not mean that God tested him, but he made of Abraham an example of the extreme boundaries of love and fear with respect to God. „For now I know that thou fearest God" (Gen. 22,12) means that God announced to all mankind how far must a human being go fearing the Almighty. According to Nahmanides Akedah as a last trial focuses on the reconciliation of the pre-knowledge of God with the human free will. God knew how Abraham would behave, but from the Abraham's point of view the trial was real; the Patriarch must have been put to trial and after standing it be awarded not only for the potential willingness to obedience, but for actual submission to God.

The only purpose of all experiences Abraham was put to was to teach humans how to act and how to believe. Particular events of Abraham's life should be an example and the lead. Through the trials the Almighty makes sure that every man is aware of the fact that submission and obedience guide to God: He is then "the LORD that doth sanctify" (Ex. 31,13). God intends to illustrate the people how strong is their faith to the truth of God's Word and how well they understood and accepted the true Nature of God. Knowing 
test był prawdziwy. Patriarcha musiał zostać postawiony przed próbą, a po sprostaniu jej został wynagrodzony nie tylko za potencjalną chęć posłuszeństwa, ale za faktyczne poddanie się Bogu. Jedynym celem wszystkich doświadczeń, jakie spotkały Abrahama, było nauczenie ludzi, jak postępować i jak wierzyć. Poszczególne wydarzenia z życia Abrahama powinny być przykładem i drogowskazem. Poprzez próby Wszechmogący upewnia się, że każdy człowiek jest świadomy tego, że posłuszeństwo i poddanie prowadzą do Boga: On jest wtedy „Panem, który uświęca” (Wj 31,13). Bóg stara się zobrazować ludziom, jak silna jest ich wiara w prawdę Słowa Bożego oraz jak dobrze zrozumieli i zaakceptowali prawdziwą Naturę Boga. Znajomość prób i pamięć o nich powinny usunąć gniew Boży i zapewnić współczucie i miłośćc ${ }^{58}$.

Rabiniczne podejście do zagadnienia prób Abrahama znane jest jedynie ograniczonemu kręgowi uczonych i niezbyt popularne poza judaizmem, choć chrześcijanie często nazywają Abrahama Patriarchą i Ojcem w wierze. Zamieszczone komentarze, wybrane na potrzeby niniejszego opracowania, odnoszą się do historycznej literatury rabinicznej. Szczególnie ważne dla badań nad próbami Abrahama są takie dzieła rabiniczne jak MBR, PRE i KJ. Istnieje więc bogata i obszerna różnorodność źródeł, które umożliwiają pogłębione badania nad każdą z prób i analizę, jaki był wynik i znaczenie tych prób dla przyszłych pokoleń. Pominięcie źródeł żydowskich zubaża możliwe wyniki badań i ogranicza wielowymiarowość życia i doświadczenia Abrahama. Korzystanie ze źródeł żydowskich pomaga lepiej je zrozumieć i pojąc rzeczywiste znaczenie Abrahama w historii zbawienia. Przedstawiony

58 Przykładem mogą być modlitwy zwane Zichronot w czasie żydowskiego Nowego Roku (Rosz Haszana). Znajduje się w nich wezwanie skierowane do Boga, aby wspominał na Akedę: „Pamiętaj, Panie, Boże nasz, o przymierzu i dobroci oraz przysiędze, którą złożyłeś Abrahamowi, naszemu Ojcu na górze Moria i rozważ zwiazanie, którym Abraham, ojciec nasz, związat swego syna Izaaka na ottarzu, jak zdusił swoje współczucie, aby petnić wolę Twoja z sercem doskonatym. Tak więc litość Twoja przezwycięży gniew Twój przeciwko nam; wielka dobroć niech odwróci Twój wielki gniew od Twego ludu, Twojego miasta i Twojego dziedzictwa" (Cylkow MRH, 2013, 301) - Zichronot na Rosz Haszana, Musaf, cytowane w: Milgrom, Binding, 70-77. 
and remembering the trials should remove God's anger and provide compassion and love57.

The rabbinical approach to the issue of the Abraham's trials is known only to limited audiences of scholars and not very popular out of Judaism, although Christians often refer to Abraham as Patriarch and Father in faith. The provided commentaries, selected for the purpose of this study refer to historical rabbinic literature. Particularly important for the studies over the trials of Abraham are such rabbinic works as MBR, PRE and BJ. Thus there is a rich and comprehensive variety of sources, which enable the in-depth studies over every single trial and analysis what was the outcome and significance of these trials for the future generations. Omission of the Jewish sources impoverishes the possible results and limits the multidimensionality of the Abraham's life and experience. Using Jewish sources helps to better understand them and the importance of Abraham in the history of salvation.

The above-presented overview of the ten trials of Abraham clearly indicates that there is a rich, extensive rabbinic literature and significant Jewish theological tradition in this respect, which should not be disregarded. Taking into account the contemporary commentaries, one may state that there is willingness and need for study of rabbinical works. The encouragement to pursue such studies is expressed e.g. in the document provided by Papal Biblical Commission "The Jewish People and Their Sacred Scriptures in the Christian Bible", dated 2001, where it is stated that "Christians can

57 Przykładem mogą być modlitwy zwane Zichronot w czasie żydowskiego Nowego Roku (Rosz Haszana). Znajduje się w nich wezwanie skierowane do Boga, aby wspominał na Akedę: „Pamiętaj, Panie, Boże nasz, o przymierzu i dobroci oraz przysiędze, którą złożyłeś Abrahamowi, naszemu Ojcu na górze Moria i rozważ zwiazanie, którym Abraham, ojciec nasz, związat swego syna Izaaka na ottarzu, jak zdusił swoje współczucie, aby petnić wolę Twoja z sercem doskonatym. Tak więc litość Twoja przezwycięży gniew Twój przeciwko nam; wielka dobroć niech odwróci Twój wielki gniew od Twego ludu, Twojego miasta i Twojego dziedzictwa" (Cylkow MRH, 2013, 301) - Zichronot na Rosz Haszana, Musaf, cytowane w: Milgrom, Binding, 70-77. 
powyżej przegląd dziesięciu prób Abrahama wyraźnie wskazuje, że istnieje w tym zakresie bogata, obszerna literatura rabiniczna i znacząca żydowska tradycja teologiczna, której nie należy lekceważyć. Biorąc pod uwagę współczesne komentarze, można stwierdzić, że istnieje chęć i potrzeba studiowania dzieł rabinicznych. Zachętę do podjęcia takich studiów wyrażono m.in. w dokumencie dostarczonym przez Papieską Komisję Biblijną „Naród żydowski i ich święte pisma w Biblii chrześcijańskiej” z 2001 r., w którym stwierdza się, że „chrześcijanie mogą się wiele nauczyć z żydowskiej egzegezy praktykowanej od ponad 2000 lat"59. Studia nad dziełami rabinicznymi mogą przyczynić się do poszerzenia wiedzy o metodach egzegetycznych i teologii tekstów biblijnych oraz poznania ich wpływu na współczesne życie człowieka. Może otworzyć się na nowy wymiar zrozumienia życia Abrahama i otworzyć nowe perspektywy.

\section{Streszczenie}

Niniejszy artykuł służy krótkiemu przeglądowi żydowskich źródeł rabinicznych w odniesieniu do Patriarchy Abrahama oraz jego doświadczeń życiowych, postrzeganych w judaizmie jako ciąg prób i testów. Od II wieku p.n.e. żydowscy autorzy uznawali szereg zdarzeń w życiu Abrahama za serię prób, stopniowo coraz bardziej wymagających i coraz trudniejszych. Poprzez te próby Bóg wypróbowywał Abrahama i jego wiarę w celu upewnienia się, że wybór Patriarchy był słuszny.. Abraham został im poddany w celu uświadomienia wszystkim, że był godny stać się założycielem narodu, oddanym służbie Bogu i wykonaniu misji powierzonej temu narodowi z Bożej woli. Zgodnie z rabiniczną tradycją ofiarowanie Izaaka było tylko jedną z wielu prób. Niniejszy artykuł, w oparciu o kilka wybranych, reprezentatywnych rabinicznych dzieł i komentarzy, przedstawi bliżej koncepcję tych prób oraz różnice, jakie można wskazać w źródłach w zakresie ich identyfikacji i kolejności.

Słowa kluczowe: dziesięć prób, Próby Abrahama, Pirke DeRabbi Eliezer, Midrasz Bereszit Rabba, Księga Jubileuszy, komentarze rabiniczne

59 https://www.vatican.va/roman_curia/congregations/cfaith/pcb_documents/ rc_con_cfaith_doc_20020212_popolo-ebraico_en.html 
learn a great deal from a Jewish exegesis practised for more than 2000 years" ${ }^{28}$. The studies over the rabbinic works may help to develop knowledge of exegetic methods and theology of biblical texts and getting acquaint what is their impact on contemporary human lives. The may enable the opening for new dimension for understanding Abraham's live and put it into new perspectives.

\section{Summary}

The paper is intended for the brief overview of the Jewish rabbinical resources with regard to Patriarch Abraham and his life experiences, viewed as a series of tests and trials. From the second century BCE the Jewish authors have been recognizing numerous events in the life of Abraham as a series of trials, gradually more and more challenging and difficult. By way of them God tested Abraham and his faith in order to assure the Patriarch's choice was right. Abraham was put to them in order to make everyone aware of his worthiness for becoming a founder of a nation dedicated to God's service and performance of a mission granted to that nation by the will of God. Pursuant to rabbinical interpretation offering of Isaac was just only one of many tests. The paper, on the basis of several representative rabbinical works and commentaries, will in more detail present the concept of these trials and differences that can be identified in the sources with respect to their identification and order.

Keywords: Ten trials, Trials of Abraham, Pirke DeRabbi Eliezer, Midrash Bereshit Rabbah, Book of Jubilees, rabbinical commentaries

\section{Bibliography}

Baker, W. - Carpenter, E. (ed.), The Complete Word Study Dictionary: Old Testament (Chattanooga, AMG Publishers, 2003)

Drazin, I. - Wagner, S.M., Onkelos on the Torah: Understanding the Bible Text, Vols 1-5 (Jerusalem, Gefen Publishing House, 2012)

Freedman, H. - Simon, M., The Midrash Rabbah. Translated into English with Notes, Glossary and Indices, (London, Soncino Press, 1961)

58 https://www.vatican.va/roman_curia/congregations/cfaith/pcb_documents/ rc_con_cfaith_doc_20020212_popolo-ebraico_en.html 


\section{Bibliografia}

Baker, W. - Carpenter, E. (red.), The Complete Word Study Dictionary: Old Testament (Chattanooga, AMG Publishers, 2003)

Cylkow I. (tłum), Machzor czyli modlitwy izraelitów na wszystkie święta część pierwsza Rosz Haszana (Kraków, Budapeszt: Austeria 2013)

Drazin, I. - Wagner, S.M., Onkelos on the Torah: Understanding the Bible Text, Vols 1-5 (Jerusalem, Gefen Publishing House, 2012)

Freedman, H. - Simon, M., The Midrash Rabbah. Translated into English with Notes, Glossary and Indices, (London, Soncino Press, 1961)

Friedlander G. (tłum., red.), Pirkei D'Rabbi Eliezer, (London, 1916), https://www. sefaria.org/Pirkei_DeRabbi_Eliezer, dostęp: 2021.02.20

Friedman, D., Bereshit: The Book of the Beginning, New Translation with Commentary, (Eugene, Wipf and Stock. 2010)

Jacobs, J., Midrash Tanhuma, A Compilation of Aggadic (Narrative) and Halakhic (Legal) Midrash). http://www.myjewishlearning.com/article/midrash-tanhuma/ dostęp: 2021.02.15

Kasher, D. (tłum.), Avot D'Rabbi Natan, 2019, https://www.sefaria.org/ Avot_D'Rabbi_Natan dostęp: 2021.02.5

Leibowitz, N., New Studies in Bereshit (Genesis) in the context of ancient and modern Jewish Bible Commentary, (Jerusalem, Maor Wallach Press, 2010)

Lumpkin, J. (red.), The Encyclopedia of Lost and Rejected Scriptures, (Blountsville: Fifth Estate, 2010)

Mack H., The Aggadic Midrash Literature, (Tel-Aviv, MOD Books, 1989)

Milgrom, J., The Binding of Isaac: The Akedah-A Primary Symbol in Jewish Thought and Art (Berkeley, Bibal Press, 1988)

Midrash Bereshit Rabbah, https://www.sefaria.org/Bereishit_Rabbah

Pirkei Awot (PA). https://www.chabad.org/library/article_cdo/aid/680274/jewish/ Ethics-of-the-Fathers.htm dostęp: 2021.02.20, w jęz. pol.: https://wolnelektury. pl/katalog/lektura/sentencje-ojcow.html (tłum. Friedman M.)

Sefaria. . https://www.sefaria.org/?home dostęp: 2021.02.15

Skolick F. (ed.), Encyclopaedia Judaica, Vols. 1-22, (Farmington Hills, Thomson Gale, 2007)

Stemberger, G., Introduction to the Talmud and Midrash, (Edinburgh, T\&T Clark, 1996)

Vanderkam, J., Jubilees, A Commentary in Two Volumes, (Minneapolis, Fortress Press, 2018)

Talmud, https://www.sefaria.org/texts/Talmud 
Friedlander G. (trans., ed.), Pirkei D'Rabbi Eliezer, (London, 1916), https://www. sefaria.org/Pirkei DeRabbi Eliezer, access: 2021.02.20

Friedman, D., Bereshit: The Book of the Beginning, New Translation with Commentary, (Eugene, Wipf and Stock. 2010)

Jacobs, J., Midrash Tanhuma, A compilation of aggadic (narrative) and halakhic (legal) midrash). http://www.myjewishlearning.com/article/midrash-tanhuma/ access: 2021.02.15

Kasher, D. (trans.), Avot D'Rabbi Natan, 2019, https://www.sefaria.org/ Avot_D'Rabbi_Natan access: 2021.02.5

Leibowitz, N., New Studies in Bereshit (Genesis) in the context of ancient and modern Jewish Bible Commentary, (Jerusalem, Maor Wallach Press, 2010)

Lumpkin, J. (ed.), The Encyclopedia of Lost and Rejected Scriptures, (Blountsville: Fifth Estate, 2010)

Mack H., The Aggadic Midrash Literature, (Tel-Aviv, MOD Books, 1989)

Milgrom, J The Binding of Isaac: The Akedah-A Primary Symbol in Jewish Thought and Art (Berkeley, Bibal Press, 1988)

Midrash Bereshit Rabbah, https://www.sefaria.org/Bereishit_Rabbah

Pirkei Awot (PA). https://www.chabad.org/library/article_cdo/aid/680274/jewish/ Ethics-of-the-Fathers.htm access: 2021.02.20

Sefaria. https://www.sefaria.org/?home dostęp: 2021.02.15

Skolick F. (ed.), Encyclopaedia Judaica, Vols. 1-22, (Farmington Hills, Thomson Gale, 2007)

Stemberger, G., Introduction to the Talmud and Midrash, (Edinburgh, T\&T Clark, 1996)

Vanderkam, J., Jubilees, A Commentary in Two Volumes, (Minneapolis, Fortress Press, 2018)

Talmud, https://www.sefaria.org/texts/Talmud

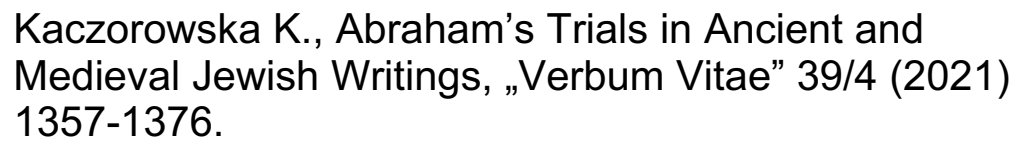

